\title{
NA SALASIE NI MA PANI LEKKO. ŻYCIE CODZIENNE PASTERZY WOLOSKICH NA SZAŁASACH NA POGRANICZU POLSKO-SŁOWACKIM W XXI WIEKU JAKO DZIEDZICTWO KULTUROWE REGIONU KARPAT (WYBÓR ZAGADNIEŃ)
}

\author{
Ewa Kocój
}

\begin{abstract}
It's not easy in the hut, ma'am". The daily life of the Vlach shepherds in the huts on the borderland between Poland and Slovakia in the 21st century as the cultural heritage of the Carpathian region (selected issues)

The purpose of this article is to present the preliminary results of the research on the shepherds' everyday life that I have been conducting since 2015 in the field of history, migration, and cultural heritage of the Vlach minority inhabiting the areas from Albania to the northern Carpathians. One of the research stages entails the studies of the daily life and rituals of the highlanders living in the huts on the Polish side of the Carpathians. The article describes the issues concerning the organization and the time-space symbolism of a modern hut, including their daily life and schedule of activities. The research was conducted in the selected huts of Spiš, Orava, Podhale, Żywiec region, and Silesian Beskids in Poland in 2015-2018. In all cases, I applied qualitative research, mostly structured and unstructured interviews with senior and young shepherds working in the huts, as well as covert and overt participant observations conducted during selected pastoral holidays and meetings in various spacesin temples, during highlander's and Vlach conventions, in theme meetings, and in the huts. I supplement these techniques with the analysis of the visual sources that I made during the field research, received from the enthusiasts of this topic, or found on the Internet. The research has shown that modern pastoralism oscillates between two poles: the traditional, which has made it possible to retain many elements from the past (cultural heritage), and the modern, thanks to which shepherds introduce global solutions to their huts and traditions.
\end{abstract}

Autor: Ewa Kocój, Uniwersytet Jagielloński, Wydział Zarządzania i Komunikacji Społecznej, Instytut Kultury, ul. prof. Stanisława Łojasiewicza 4, 30-348 Kraków, Polska, e-mail: ekocoj@poczta.onet.pl, ORCID iD: https://orcid.org/0000-0002-2057-4736

Słowa kluczowe: dziedzictwo kulturowe - Karpaty - szałaśnictwo - pasterstwo - sezon pasterski - życie codzienne - polsko-słowackie pogranicze - tradycje wołoskie

Keywords: culture heritage - Carpathians - huts - The daily life - the shepherding season - the Polish-Slovak borderland - vlachs tradition

Balcanica Posnaniensia. Acta et studia, XXV, Poznań 2018, Wydawnictwo Instytutu Historii UAM, pp. 269-295 ISBN 978-83-65663-94-8, ISSN 0239-4278. Polish text with a summary in English.

doi.org/10.14746/bp.2018.25.15 


\section{WPROWADZENIE, CEL I METODOLOGIA}

Szałaśnictwo i związane z nim pasterstwo stanowi od wieków jedną z najbardziej tradycyjnych profesji w przestrzeni Karpat, znaną tu zapewne od czasów starożytnych. Łączność geograficzna Karpat i łańcuchów górskich na Bałkanach przy jednocześnie bardzo słabej ich kontroli przez ośrodki polityczne sprzyjały migracjom i tworzeniu się wspólnoty tradycyjnej profesji pasterstwa górskiego na całym tym obszarze. Postępujące co najmniej od XIII-XIV wieku osadnictwo pasterzy we wsiach i ich przejście $\mathrm{z}$ wędrownego do półwędrownego stylu życia nie likwidowało całkowicie ich mobilności, wzajemnych kontaktów, a nawet migracji. Wprowadzane wraz osadnictwem prawo wołoskie zapewniało pasterzom znacznie więcej swobody niż pozostałej ludności chłopskiej, a rozległe granice państwa węgierskiego i polityka osadnicza królów Węgier spowodowały, że pasterze wołoscy mogli swobodnie wypasać owce i bydło oraz osiedlać się na nowych terenach. Do ich obowiązków należało przede wszystkim strzeżenie rubieży oraz płacenie podatków ${ }^{1}$. Okresowe związki polityczne Węgier z Polską i Rusią Halicką sprzyjały rozszerzaniu się osadnictwa wołoskiego na pograniczne obszary tych państw, stanowiących wkrótce jedną Koronę Królestwa Polskiego. Proces ten nasilił się jeszcze poprzez bliskie związki z Mołdawią. Pasterstwo na tym terenie ulegało w ciągu wieków licznym przemianom takim jak: "prywatyzacja" obszarów górskich, próby jego ograniczania np. poprzez zalesianie gór w XIX wieku i całkowitą niemal jego likwidację w XX wieku. Dzisiejsze pasterstwo odbudowujące się na pograniczu polsko-słowackim jest niewątpliwie skutkiem tych wszystkich procesów, które miały miejsce w przeszłości.

Pomimo nasilonych w ostatnich latach badań naukowych dotyczących historii karpackiego pasterstwa, dróg jego europejskich migracji oraz dziedzictwa kulturowego, które pozostawiło po sobie w sferze materialnej i niematerialnej, wiele elementów stanowi wciąż dla badaczy wielkie wyzwanie. Podjęte w ostatnim czasie nowe projekty naukowe dotyczące rozmaitych aspektów historii i kultury wołoskiej przyniosły wiele nieznanych wcześniej konstatacji, jednak dzieje pasterzy wołoskich pozostają nieciągłe, pełne luk i niewyjaśnionych zagadnień2 ${ }^{2}$. Wynika to przede wszystkim

${ }^{1}$ Szerzej na ten temat: G. Jawor, Osady prawa wołoskiego $i$ ich mieszkańcy na Rusi Czerwonej w późnym średniowieczu, Lublin 2004.

${ }^{2}$ Warto zwrócić uwagę na nowe badania dotyczące kwestii aromańskich i wołoskich, zob. m.in.: Abadzi H., The Vlachs of Greece and their Misunderstood History, https://www.academia.edu/3804965/ The_Vlachs_of_Greece_and_their_Misunderstood_History_English [dostęp: 24.112015]; N.S. Balamaci, Can the Vlachs write their own history?, "Journal of Hellenic Diaspora" 1991, 17, Januar, pp. 9-36, http:// pl.scribd.com/doc/46327940/Can-the-Vlachs-Write-Their-Own-History\#scribd [dostęp: 31.10.2015]; I. Czamańska, Wolosi i Stowianie w średniowieczu i epoce nowożytnej, „Res Historica”, 2016, n. 41, 42, ISSN: 2082-6060, ss.11-23; I. Czamańska, The Vlachs - several research problems, „Balcanica Posnaniensia Acta et studia, v. 22, n. 1, s. 7-16; E. Kocój E., The Story of an Invisible City. The Cultural Heritage of Moscopole in Albania. Urban Regeneration, Cultural Memory and Space Management [w:] Intangible heritage of the City. Musealisation, preservation, education, ed. By M. Kwiecińska, Kraków 2016, ss. 267-280; M. Kiereś, Współczesny kontekst zmian w obyczajowości tradycyjnej kultury paster- 
z oralnego charakteru kultury pasterskiej, która długo nie była przedmiotem zainteresowania badawczy i w związku z tym, nie pozostawiła po sobie wielu źródeł pisanych. Jej dogłębnemu poznaniu niesprzyjało także wewnętrzne zamknięcie kulturowe samych pasterzy, którzy zachowywali wiele elementów swojej tradycji w tajemnicy przed obcymi.

Wychodzę z założenia, że pasterstwo w sferze materialnej i niematerialnej należy obecnie rozpatrywać pod kątem dziedzictwa kulturowego Europy, tym bardziej, że sami pasterze i społeczności lokalne związane w przeszłości z tradycją pasterską pogranicza polsko-słowackiego coraz częściej też odwołują się do takiego znaczenia pasterstwa. Jego cechy charaktersytyczne mieszczą się w założeniach konwencji UNESCO z 2003 roku o ochronie niematerialnego dziedzictwa kulturowego zwanej Living Human Treasures System, który nawiązał do realizowanego już od lat 50-tych XX wieku w Japonii i innych krajach świata projektu ochrony działań lokalnych społeczności w zakresie tradycyjnej kultury ${ }^{3}$. Wśród kategorii ,zabytki niematerialne” znalazły się w niej m.in. tradycje, ustne przekazy, zwyczaje, obrzędy i rytuały związane ze świętami charakterystycznymi dla danej kultury lub kilku kultur, język, widowiska, wiedza związana ze wszechświatem i przyrodą oraz charakterystyczne dla nich praktyki rytualne, jak również umiejętności związane z rzemiosłem tradycyjnym. Aby ich wpis na listę UNESCO był możliwy, zabytki te muszą być przekazywane w znacznej części drogą ustną z pokolenia na pokolenie, a ich obecność ma wzmacniać poczucie tożsamości lokalnej społeczności i stanowić gwarancję jej zrównoważonego rozwoju ${ }^{4}$. W Polsce pasterze rozpoczęli już także działania na rzecz wpisania szałaśnictwa na listę niematerialnego dziedzictwa kulturowego UNESCO, a ich finał - wobec rozmiaru prac przez nich przedsięwziętych - wydaje się być nie tak odległą perspektywą. Dla antropologicznych rozważań ważne jest w jakie zależności wchodzą ze sobą poszczególne elementy dziedzictwa kulturowego - wpisane na listę UNESCO, znajdujące się w trakcie przygotowań do wpisu oraz odrzucone. Przeszło pół wieku dokonywania wpisów na listy zabytków materialnych UNESCO i ponad dekada wpisów arcydzieł niematerialnych, pozwalają bowiem badaczom z tzw. nurtu krytycznego nad zabytkami dziedzictwa kulturowego, dokonać pewnej analizy problematyki i dostrzeć zmiany dokonujące się w obszarze tych zjawisk kultury, które zostały wpisane na owe listy. Badania naukowe przynoszą w tym względzie niejednoznaczne rezultaty i pokazują, że skutki powiększającej się listy arcydzieł UNESCO

\footnotetext{
skiej w Karpatach, Kultura pasterska we współczesności karpackiej z uwzględnieniem regionu Babiej Góry, red. B. Rosiek, K. Słabosz-Pałacz, Zawoja 2015; T. KAHL, A. PASCARU, Rrāmānj und Armānj. Wie einheitlich sind Kultur, Sprache und Identität der Aromunen?, „Quo vadis Romania”, 2018, 50, s. 5177; Sajkowski, The Peoples Inhabiting the Illyrian Provinces Known under the Name of Morlachs Definition of the Ethnonym in the Light of the French Literature, „Res Historica”, 2016, 41, s. 111-123.

${ }^{3}$ Guidelines for the Establishment of National "Living Human Treasures" Systems, http://www. unesco.org/culture/ich/doc/src/00031-EN.pdf [dostęp: 03.08.2015].

${ }^{4}$ Dziedzictwo niematerialne, http://www.unesco.pl/kultura/dziedzictwo-kulturowe/dziedzictwo-niematerialne/ [dostęp: 02.08.2017].
} 
możemy mierzyć w dwóch wartościach - pozytywnej i negatywnej; o tej drugiej rzadko na razie wspomina się i pisze, traktując ją jako „rzecz wstydliwą”, z którą nie do końca wiadomo co uczynić. Jeszcze rzadziej pisze się i bada dziedzictwo „odrzucone", pod którym, w kontekście tego artykułu, rozumiemy zabytki kultury materialnej i niematerialnej nominowane do wpisów na listy UNESCO i przez organizację tę odrzucone, jako niespełniające kryteriów zabytkowości. Również interesujące dla antropologów kulturowych są badania dotyczące dziedzictwa, które przeszło drogę wpisu - w tym kontekście warto postawić pytania o to, jak zmienia się dane zjawisko kulturowe oraz co dzieje się w społecznościach lokalnych w momencie, gdy przechodzi z tzw. undergroundu do mainstremu (z dziedzictwa społeczności lokalnej do globalnej) $)^{5}$. Z tego powodu, szałaśnictwo i pasterstwo są dobrymi obszarami badań antropologicznych - w najbliższym czasie będą ulegały licznym przeobrażeniom związanym z wpisem na listy zabytków UNESCO oraz unijnymi programami związanymi z ich finansowaniem.

Przystępując do eksploracji w obszarze pasterstwa, postawiłam sobie kilka pytań badawczych. Interesowało mnie przede wszystkim, jakie jest oblicze współczesnej kultury pasterskiej w Karpatach, a w szczególności określenie, kim są współcześni pasterze, w jaki sposób praktykują swoją profesję, jak wygląda ich rytm życia w ciągu roku oraz czym jest dla nich pasterstwo? Przedmiotem antropologicznej obserwacji i refleksji stało się również to, jak żyją w XXI wieku pasterze (bacowie, juhasi), jakie elementy tradycyjnego pasterstwa zachowały się, a jakie nie, i w jakim kierunku postępują zmiany. W zbiorowej pamięci mieszkańców tego obszaru pasterstwo zajmuje miejsce znaczące, choć - w zależności od statusu społecznego współczesnych górali lub przyjezdnych osiadłych w rejonach górskich - różnie wartościowane. Chciałam również przyjrzeć się organizacji współczesnego szałasu, jego czasowo-przestrzennej symbolice - światu ich topograficznych wyobrażeń, momentom, w których współcześni pasterze rozpoczynają i kończą wypas, temu, jak wygląda ich codzienność, jaki mają rozkład zajęć w ciągu doby, a także co jedzą i skąd pozyskują pożywienie. Badania te mają także inny cel - po rozpoznaniu specyficznych cech pasterstwa polsko-słowackiego pogranicza chciałabym porównać go z pasterstwem Ukrainy, Rumunii - i szerzej - Bałkanów, aby pokazać podobieństwa i różnice w zakresie terminologii, wierzeń, obrzędów i rytuałów, jak również szałaśniczej gospodarki.

$\mathrm{W}$ tej części prezentuję wstępne wyniki badań dotyczących życia codziennego pasterzy na szałasach w XXI wieku, przeprowadzonych na bacówkach Spisza, Orawy, Podhala, Żywiecczyzny i Beskidu Śląskiego w Polsce w latach 2015-2018. Uzupełniam je obserwacjami i wywiadami prowadzonymi przeze mnie podczas redyku wiosennego rodziny Szczechowiczów, podczas którego w dniach 19-24 kwiet-

${ }^{5}$ E. Kocój, Dziedzictwo kulturowe mniejszości narodowych, etnicznych i religijnych kręgu Karpatnarracje lokalne $i$ zarzadzanie instytucjonalne (wstępne rezultaty badania pilotażowego), „Prace Etnograficzne", 2016, z. 3, s. 193-213; E. Kocój, Sacrum i przestrzeń. Hierotopia wyspy Kefalonii w Grecji (wstępne rezultaty badania pilotażowego), „, Łódzkie Studia Etnograficzne”, 2017, 56, s. 125. 
nia 2018 roku wraz z trzema bacami i około 500 owcami pokonałam trasę o długości 110 km z Ratułowa na Podhalu do Soblówki na Żywiecczyźnie. We wszystkich przypadkach zastosowałam podejście jakościowe, przede wszystkim wywiady standaryzowane i swobodne prowadzone z bacami i juhasami pracującymi na szałasach, jak również obserwacje uczestniczące jawne i ukryte dokonane podczas wybranych świąt i spotkań pasterskich w różnych przestrzeniach - w świątyniach, podczas zjazdów góralskich i wołoskich, tematycznych spotkań i na szałasach. Techniki te uzupełniłam analizą źródeł wizualnych, jakie wykonałam podczas badań terenowych, jak również użyczonych mi przez pasjonatów tematu i odnalezionych w Internecie.

\section{WSPÓŁCZESNE PASTERSTWO - MIĘDZY TRADYCJĄ A NOWOCZESNOŚCIĄ}

Gdyby dokonać szybkiego podsumowania współczesnego pasterstwa, można śmiało i żartobliwie (ale bez złośliwości) powiedzieć, że jego najbardziej widocznym symbolem jest współczesny baca, który posiada... furę, skórę i komórę; do tego jeszcze stado owiec, szałas i góralski strój, który ubiera od święta lub wtedy, kiedy chce. Ma też całoroczny dom i ,jak Bóg da" - żonę i kilkoro dzieci. Jego życie dzieli się na dwie części uzależnione od pór roku: wiosenno-letnią (kwiecień-październik), w której wypasa stada, prowadzi przetwórstwo mleka i wyrób serów, oraz jesienno-zimową (listopad-marzec), w której mieszka w domu i zajmuje się innymi pracami gospodarskimi, w tym przygotowaniem do wiosenno-letniego wypasu w kolejnym sezonie. Granica tych okresów i jej przekraczanie są zaznaczone do dziś bogatą obrzędowością pasterską, podkreślającą ich odmienne funkcje i związane z nimi znaczenia ${ }^{6}$. Gdyby zapytać pasterzy, która z części roku jest ważniejsza, bez wahania odpowiedzą - ta pierwsza, wiosenno-letnia, związana z wypasem. Czekają na nią zazwyczaj całą zimę, nie wyobrażając sobie, by moment wyruszenia na szałasy mógł nie nadejść - dla organizacji ich profesji, ale także z punktu widzenia sensu ich życia brak wypasu oznaczałby swoisty „koniec świata”, niosąc specyficzne duchowe cierpienie. Czas wypasu przypomina w pewnien sposób okres kilkumiesięcznego święta, choć wiąże się z nim przecież ciężka fizyczna praca zapewniająca większości rodzin całoroczne utrzymanie. Samo wyruszenie w drogę, długi pobyt poza przestrzenią domu, wreszcie specyficzne reguły panujące na szałasach powodują, że czas ów odgradza się od czasu profanum (jesienno-zimowego) określonymi obrzędami i rytuałami. Powtórzmy: dla współczesnych baców czas święta to czas wypasu, a czas profanum to okres jesieni

${ }^{6}$ G. Kopczyńska-Jaworowska, Gospodarcze i społeczne podstawy pasterstwa tatrzańskiego, [w:] Historia osadnictwa i organizacja społeczna pasterstwa oraz stownictwo pasterskie, oprac. S. Górzyński [et al.]., Seria: Pasterstwo Tatr Polskich i Podhala, Wrocław 1962, s. 107-162; M. Kiereś, Wspótczesny kontekst zmian $w$ obyczajowości tradycyjnej kultury pasterskiej w Karpatach, Kultura pasterska we wspótczesności karpackiej z uwzględnieniem regionu Babiej Góry, red. B. Rosiek, K. Słabosz-Pałacz, Zawoja 2015. 
i zimy, kiedy zamiera życie na halach i pasterze przenoszą się do domów rodzinnych. Ten swoisty świat „na opak” tworzy rzeczywisty podwójny świat pasterzy, którzy choć żyją w XXI wieku, są jednocześnie stąd i stamtąd - z tego i z własnego świata.

Aby dobrze poznać współczesne pasterstwo, trzeba zdać sobie sprawę z tego, że podstawowe elementy organizacji życia dorocznego i codziennego mają za sobą wielowiekową historię. Chociaż pamięć współcześnie żyjących pasterzy dotycząca ich profesji sięga zazwyczaj pokolenia ojców i dziadków, ewentualnie - rzadko - pradziadków, a ze względu na oralny charakter kultury pasterskiej posiadamy niewiele pisanych źródeł etnograficznych jej dotyczących sprzed XIX wieku, badacz przebywający na szałasach i prowadzący badania wśród tej społeczności po pewnym czasie dostrzega, że specyficzne formy życia pasterskiego musiały ukształtować się w bardzo odległej przeszłości i że trwają od stuleci w takiej samej postaci przekazywane drogą ustną i poprzez „wtajemniczanie w tajniki” profesji. Sami pasterze podkreślają zresztą z dumą ten aspekt zawodu powołując się często na swoich nauczycieli - starszych baców, często jeszcze żyjących: ,ja sie uczył u bacy Franosa”, ,ja się uczył na Biescadach", ,ja się uczył u takiego starego bacy", ,,ja sie ucył u baców tatarzańskich"”. Podobnie - współcześni pasterze podkreślają również stopnie hierarchii jako odwieczna drogę, jaką każdy z nich musi przejść w tej profesji:

Juhas, jest honielnik to jest ten co pomaga paśc lub pasie, ale napędza owce do doja, to jest honielnik, głowne jego zajęcie to jest naganianie owiec do doja. Mamy bacę, on jest najważniejszy, baca się staje od tego czasu jak się zrobi papiery, jak się ma swoją bacówke, on wszystkiego dogląda. Był też podbaca, takie pojęcie było, nawet jest do teraźnia, jak to powiedzieć, dawniej baca to cały cas siedzioł na bacówce. Teraz bacowie nie siedza na bacówce, niektórzy siedzą coły czos, jak my tu siedzimy coły czas, ale sa tacy bacowie, co nie siedza i jest podbaca i on zarządza, jak go nie ma, ale slucho się bacy, ale on rzadzi juhasami, a juhasi mają go słuchac. A honielnik to jest taki najniższy stopień, poczatkujący, nagania owce do doja, to jest jego głowne zajęcie. Ja też tak zatrzynał, ja zacyznał od 8 roku życia, wtedy byłem honielnikem, juhasem zaczołem być jak żem skończył podstawówkę, bo nie poszedłem do szkoły, tylko zaraz na bacówkę, juhas to jak już owce doi ${ }^{8}$.

Nie oznacza to, że pasterstwo się nie zmienia, że pozostało reliktem przeszłości ma ono bowiem i chyba zawsze miało swego rodzaju podwójne oblicze: jest zarazem tradycyjne i nowoczesne, zachowując istotę tego, co „stare”, jednocześnie z łatwością wprowadza to, co „nowe”, przydatne z punktu widzenia współczesnego życia. Oto kilka przykładów. Stare, drewniane, ciągnięte przez konie wozy, którymi jeszcze w latach 70.- 90. XX wieku na rozpoczęcie sezonu pasterskiego wyruszali bacowie z dobytkiem na szałasy, zastąpiły obecnie samochody osobowe lub terenowe. Pasterze wożą nimi cały dobytek konieczny do życia w szałasie - jedzenie, naczynia, sprzęt gospodarski, wyposażenie szałasu (np. kołdry, poduszki, materace), a nawet jak trzeba - zwierzęta. Wyjazd z domu na szałasy na rozpoczęcie sezonu pasterskie-

\footnotetext{
${ }^{7}$ Badania terenowe (dalej w tekście stosuję zapis: BT) spotykane powszechnie na Spiszu, Orawie, Podhalu.

${ }^{8}$ BT, wywiad z bacą Janem Hyrczykiem, Baligówka (Czarny Dunajec), sierpień 2017.
} 
go przypomina rodziny koczowników przenoszące cały swój dobytek, już nie - jak dawniej - na jucznych zwierzętach, ale na samochodach. Archaiczne sposoby zapisu przy mirowaniu (czyli odmierzaniu ilości mleka dawanego przez owce na początku sezonu pasterskiego), tzw. karbiki - tabliczki, patyczki lub kije kontrolne, na których karbowano liczbę owiec i ilość dawanego przez nie mleka, jakimi w 1. połowie $\mathrm{XX}$ wieku, a nawet całkiem niedawno (choć wtedy już sporadycznie) posługiwali się bacowie i juhasi, zamienione zostały na kartki papieru i długopisy, a wyniki umieszczane są nierzadko w komputerach. Zaklęcia i czary przeciw ukąszeniu żmiji, jakie jeszcze w II połowie XX wieku wykorzystywali na szałasach bacowie, nie wytrzymały konkurecji z lekarstwami, w jakie zaopatrzona jest każda bacówka na hali ${ }^{9}$. Zakaz przebywania na bacówkach i halach kobiet do dnia św. Jana Chrzcicela (24 czerwca), wynikający z wierzeń w demony pojawiające się pod postacią kobiet i zagrażające pasterzom, znany jeszcze współcześnie wielu bacom w Polsce, przestał obowiązywać w realiach współczesnego pasterstwa - z powodu niewielu juhasów chętnych do podejmowania pracy w pasterstwie oraz złej jakości pracy wielu z nich bacowie coraz chętniej korzystają z pomocy kobiet (praktyka często spotykana na tzw. bacówkach rodzinnych), bywają też bacówki prowadzone przez kobiety bacynie. Taka sytuacja ma miejsce m.in. w „Bacówce u Jancoka” w Brzegach k/Bukowiny Tatrzańskiej, gdzie funkcję bacy pełni od ponad 20 lat Janina Rzepka, która określana jest jako ,„pierwsza zawodowa kobieta-baca w Polsce" 10 . Podobna sytuacja występuje na bacówce rodziny Chrząszczów z Jeleśni na Żywiecczyźnie, gdzie funkcję bacy pełni oficjalnie od 22 lat Piotr Chrząszcz, ale we wszystkich pracach uczestniczy jego żona Magdalena, która wykonuje na bacówce wszystkie czynności: doi owce, wyrabia i sprzedaje sery, gotuje, sprząta, karmi inwentarz, udziela informacji turystom ${ }^{11}$. Również w rodzinie Miętusów z Miętustwa na Podhalu, gdzie funkcję oficjalnego bacy pełni Bolesław Miętus, ze względu na prace rolnicze, które musi on wykonywać w domu, funkcję podbacy i juhasa przejmuje jego córka Teresa, przebywająca na szałasach z owcami pod Babią Górą w całym sezonie pasterskim ${ }^{12}$. Wiele kobiet włącza się również w proces wytwarzania produktów mlecznych, przede wszystkim serów oraz w jego zbyt - dobrym przykładem jest tu Anna Wilczek z Kacwina, która w sezonie pasterskim pomaga mężowi w wyrabianiu serów i sprzedaje je na targu w Jabłonce (każda środa miesiąca, od kwietnia do września) oraz w Nowym Targu (każdy czwartek mie-

${ }^{9}$ BT, Jeleśnia, wywiad z Tadeuszem Szczechowiczem seniorem, maj 2015; badania terenowe, obserwacja uczestnicząca podczas redyku rodziny Szczechowiczów, kwiecień 2018, kiedy baca Tadeusz Szczechowicz zastosował zstrzyki z penicyliny chorującej owcy.

10 Śladami tradycyjnego wypasu owiec. Zrównoważone rolnictwo w polskiej części Karpat. Przewodnik, opr. B. Dąbek, B. Jabłońska, E. Jurkiewicz, M. szewczyk, J. Michałek, K. Król-Łegowski, Warszawa 2016, s. 54.

11 BT, wywiad z Piotrem i Magdaleną Chrząszcz, Jeleśnia, maj 2015 oraz kwiecień 2018 roku.

12 BT, wywiad z podbacyniąTeresą Miętus, Polana pod Leśniczkówką (okolice Hali Śmietanowej), Zubrzyca Górna, sierpień 2017. 
siąca, od kwietnia do września) ${ }^{13}$. Również Marcelina Pluta z Rzepisk na Spiszu pomaga rodzinie $\mathrm{w}$ pracy na szałasie oraz $\mathrm{w}$ sprzedaży produktów mlecznych $\mathrm{w}$ sezonie na bacówce w Nowinach ${ }^{14}$. Sami pasterze, choć jeszcze do niedawna wyznawali tego typu wierzenia i stosowali rozliczne sposoby zapobiegania rzekomym nieszczęściom sprowadzonym na szałasy przez kobiety, obecnie powoli dystansują się do tych wierzeń i obrócili je w żarty: „no, tak było, niektórzy kobiet na bacówkach nie przyjmowali, ale my zawsze chętnie kobiety przyjmujemy”, ,e, to takie zabobony były". ${ }^{15}$ Pokazuje to, że pasterze żyją tradycją (rytm pór roku i cyklu dobowego, transport ekwipunku, bliski kontakt ze zwierzętami, praca grupowa i ścisły podział obowiązków), ale jednocześnie zmiany w niej zachodzące pod wpływem dochodzących do nich nowych trendów i kulturowych idei, traktują jako naturalny proces, który włączają w swoje dziedzictwo kulturowe.

Aby poznać życie na szasie, trzeba wyraźnie podkreślić, że współcześni pasterze rozgraniczają dwa znaczenia terminu „szałas” - węższe, gdy oznacza ono pojedyczną budowlę wzniesioną na hali, na polanie lub w lesie (określaną także w różnych wariantach regionalnych i dialektologicznych jako sałas, szałasz, sałasz, szałas, kolyba, kolibka), i szersze, w którym pod terminem szałas (z wariantami sałas, szałasz, sałasz, szałas) kryje się specyficzne gospodarstwo pasterskie, rodzaj spółki szałaśniczej rządzącej się specjalnymi prawami i relacjami, w które wchodzą ze sobą osoby zarządzające (baca), zarządzane (pracownicy szałasu - podbacowie, juhasi-wałasi, honielnicy), właściciele ziemi, klienci (gazdowie) oraz nabywcy (klienci - tzw. miejscowi, firmy oraz turyści). Można zaryzykować twierdzenie, że szałas w tym drugim znaczeniu obejmuje sfery materialną i duchową oraz że niezwykle istotne są relacje, które łączą owe sfery. Relacje te opierają się na wzajemnych zależnościach wszystkich stron. Dodajmy, że formowanie spółki szałaśniczej wymaga również poczynienia ustaleń zależności między bacą, właścicielami ziem, na których baca wypasa stada, właścicelami owiec, którzy powierzają mu je na czas wypasu, ustalenia podziału zysku (rozliczeń w gotówce, przetworach mlecznych ${ }^{16}$. Jest to często bardzo trudne zadanie, ponieważ każdy baca musi zazwyczaj „,dogadać” się z kilkunastoma, a nawet kilkudziesięcioma osobami. Tak, jak w wiekach XIX i XX, są to umowy ustne, za którymi wciąż stoi słowo i honor obu stron. Zmienił się jednak czas zawierania umów pomiędzy stronami - w przeciwieństwie do dawnych zwyczajów, które ustalane były w każdym roku na wiosnę, obecnie „dogadywane” są przez cały jesienno-zimowy okres. To, co pozostało z dawnych czasów, to forma tych umów - jak mówią sami bacowie, są one zawierane na „gębę”, czyli ustnie, bez potwierdzenia na papierze, a każda ze stron poczyta sobie za honor ich dotrzymywanie. W rzeczywistości uważny badacz dostrzeże w nich pozostałości z dawnych zwyczajów ludów nomadycznych, do któ-

\footnotetext{
${ }^{13}$ BT, Targ w Jabłonce, obserwacja uczestnicząca, 2015-2018.

${ }^{14}$ BT, wywiad z bacą Tadeuszem Szczechowiczem seniorem, redyk wiosenny, kwiecień 2018.

${ }^{15}$ BT, wywiad z bacą Andrzejem Zubkiem, Dusztyn, sierpień 2017.

${ }^{16}$ Szerzej na ten temat $w$ kolejnych publikacjach.
} 
rych doszły następnie elementy średniowiecznych stosunków społecznych (kodeks honorowy), regulacje prawa wołoskiego oraz społecznego, gdzie za punkt honoru uznawano „dane komuś słowo”, oznaczające zaciągnięcie zobowiązania względem kogoś, przysięgę, złożenie przyrzeczenia. Pasterze, którzy zawarli ze sobą takie honorowe porozumienie, używali i wciąż jeszcze używają na jego określenie formuły słownej „,mieć z kimś mir” (,„mam z nim mir”, „,mają ze sobą mir”), czyli mieć z kimś zgodę, porozumienie ${ }^{17}$. Zobowiązania te traktują poważnie, bowiem stanowią one dla nich możliwość kontynuowania tradycyjnej profesji, którą lubią i poważają, jak również która jest źródłem zarobku pozwalającą im utrzymać się na różnym poziomie ekonomicznym (w zależności od rozmiaru szałasu i współpracy z gazdami).

\section{ŚWIT}

Wypasowy sezon pasterski współcześnie rozpoczyna się na wiosnę i zależy przede wszystkim od pogody. Jeżeli wiosna jest słoneczna, a trawy szybko rosną, pasterze pogranicza polsko-słowackiego wyruszają z owcami na szałasy i hale zazwyczaj już w połowie kwietnia. Gdy wiosna jest zimna czy wręcz mroźna, moment wyruszenia na wypas może zostać przesunięty aż na początek maja. Od tej chwili ich codzienne życie zmienia się i biegnie przez około 5-6 miesięcy w innym, ściśle uregulowanym cyklu dobowym, pozwalającym pasterzom na dzielenie czasu każdego dnia według specyficznego rytmu. Można również powiedzieć, że roczny cykl pasterzy dzieli się wyraźnie na 2 części: wiosenno-letni i jesienno-zimowy. Czas wiosenno-letni urasta $w$ ich wypowiedziach i obserwacji zachowań do czasu sacrum, który objawia sie również w przestrzeni sacrum - są nimi sezon pasterski i szałas. W zachowaniach pasterzy szałas staje się specyficzną semiosferą - wokół niego objawia się świat ich wyobrażeń dotyczących otaczającej rzeczywistości, wierzenia, gesty, obrzędy i rytuały, które ukazują symboliczny wymiar czasu i sensów, jakie nadają oni szałaśniczej przestrzeni. Rytm czasu jest taki sam w każdym dniu tygodnia, bez względu na dzień powszechny, niedzielę czy przypadające w sezonie pasterskim święta.

Życie codzienne pasterzy w sezonie wypasu rozpoczyna się i kończy prawie zawsze w ciemności. W cyklu dobowym szczególną wartość mają dwa momenty związane ze Słońcem - jego zachód i wschód. Obserwacje zachowań pasterzy pokazują, że ich aktywność rozpoczyna się i wzmaga się oraz maleje i kończy w momentach granicznych - w czasie przejścia nocy w dzień i dnia w noc. Te dwa momenty można nazwać filarami czasu pasterzy, wokół których zbudowane jest ich cała aktywność oraz praca. Gesty i praktyki rytualne, które wówczas wykonują (przeżegnania, modlitwy, formuły magiczne, podział ról i wypowiedzi), odsyłają do archicznych wyobrażeń czasu, jakie charaktersytyczne są dla społeczności tradycyjnych, dzielących dobę

${ }^{17}$ BT, spotkane powszechnie na Spiszu, Podhalu, Orawie, w Beskidzie Śląskim i Żywieckim. 
na 2 części: dobrą (świt-dzień) i złą (wieczór-noc) ${ }^{18}$. Pierwsza z nich to czas działalności pasterzy, którzy wykonują w niej czynności wiążące teraźniejszość z przeszłością, w ich rozumieniu tradycją ojców i dziadów, a w dalszych konotacjach przodków (także wołoskich), którzy przybyli tu dawno temu z różych terenów, osiedlając się i wykonując na szałasach podobne czynności, jakie wykonują oni „tu i teraz”. Druga, związana z nocą, to czas działania „nie-pasterzy” - to wraz z nadejściem tej części doby pasterze czują, jakby w ich życie wkraczały inne moce. Mogą wiązać się z nią różne niebezpieczeństwa ze strony złych sił, demonów, strachów czy niebezpiecznych zwierząt, wobec których pasterze czują się bezradni. Współcześni pasterze opowiadają o nich niechętnie, ale kiedy już zdecydują się uchylić rąbka tego świata, odłania się całe spektrum ich wyobrażeń o uniwersum:

\begin{abstract}
Było tak w Jabłonce nad jeziorem, było tak, mielimy tam dziewięć psów duzych, i juhas powiedział tak, taki dobry juhas, taki z roku na rok, juhos powiedział, ze jesce cegoś takiego nie widział, coś było, ino nie wiadomo co, czy wataha wilków lub niedźwiedź, był niedźwiedź, tak ze dziewięć psów scekało w jednym miejscu, ale nie sły dalej, przewożnie lecą psy, lecą jak tu ktoś ucieko, ale nie uciekał, jakby to wilki były, to by uciekały, albo dużo wilków albo niedźwiedź, psy wycuwały, tako obchodziło ten kosor, i psy tyż obchodziły razem to coś, a blizej cłowieka i blizej owiec to psy mocniej scekają i to wtedy to uciekło to coś jak juhas wstoł i zacął krzykać, dryć sie, to psy nabrały śmiałości, zacął juhas lecieć z kijami, to psy nabrały śmiałości, to coś uciekło i wtedy psy poleciały, ale podejrzewam, ze to mógł być niedźwiedź, tam ni ma niedźwiedzi, ale mógł przechodzić, psy nie znają niedźwiedzia, a niedźwiedź potężny ${ }^{19}$.
\end{abstract}

Początek dnia przypada u współczesnych pasterzy zazwyczaj w momencie przejścia nocy w świt - około 4 rano i wiąże się z czynnością dojenia owiec. Są też tacy bacowie, którzy wstają każdego dnia o godzinie 3 nad ranem - zależy to od liczby wypasanych owiec oraz od liczby osób je dojących. Baców budzi zazwyczaj dźwięk alarmu w komórce lub tradycyjny budzik; niektórzy budzą się sami - dotyczy to przede wszystkim baców z długoletnim doświadczeniem, których organizm po wielu latach pracy tak przystosował się do wczesnego wstawania, że by się obudzić, nie potrzebują żadnych urządzeń technicznych. Wstawanie w ciemności nie jest łatwe, stąd młodsi pasterze starają się przeciągnąc moment wstawania choćby o kilka minut. Tuż po obudzeniu pasterze śpiący w bacówce dokładają do watry, aby ogień rozświetlił przestrzeń. Jest to ważny moment, ponieważ ogień ten, w przeszłości miał symboliczne znaczenie, a gesty współczesnych pasterzy odsyłają do archaicznych znaczeń związanych w świecie pasterskim z żywą watrą - była ona w Karapatach uznawana za opiekuna przestrzeni i osób w niej zamieszkujących, dawała światło i ciepło, tak ważne w codziennym życiu na szałasie. W niektórych regionach Karpat sakralizowano ją

18 E. Kocój, Pamięć starych wieków. Symbolika czasu w rumuńskim kalendarzu prawosławnym, Kraków 2013.

19 BT, wywiad z bacą Janem Hyrczykiem, Baligówka (Czarny Dunajec), sierpień 2017. 
i utożsamiono ją z Bogiem lub świętymi-opiekunami szałaśniczej przestrzeni i stad ${ }^{20}$. Symbolikę tego ognia można dostrzec do dziś na szałasach, choć odnajdujemy ją już przede wszystkim w zachowaniach pasterzy (nie w ich wypowiedziach) - splata się on z codzienną pracą pasterzy - jest towarzyszem każdej pracy na szałasie i gaśnie wówczas, kiedy gaśnie ich aktywność.

Gdy w bacówce nie ma prądu, większość czynności współcześni pasterze wykonują prawie w całkowitej ciemności roświetlonej jedynie watrą lub latarką. Wiekszość z nich zagotowuje również w kociołku wodę potrzebną do wykonania serów, a także do innych porannych czynności gospodarskich. Moment pobudki jest też zazwyczaj czasem przeżegnania się i rozpoczęcia dojenia owiec - pośpiech i liczba owiec sprawiają, że bardzo często, co podkreśla większość pasterzy, brakuje czasu na poranny posiłek. Niektórzy wszakże podkreślają, że nie potrafią zacząć dojenia bez wypicia kawy; jeszcze inni żartują, że jak juhas jest sprytny, to zawsze zdąży przygotować coś ciepłego do picia. Najczęściej jednak, jak wspomniałam, dzień rozpoczyna się od dojenia owiec bez spożycia posiłku:

Na bacówce my tu wstajemy różnie. Np ten pan co tu idzie, wstaje codziennie o trzeciej po północy, dzień na dzień, i my też tak wstajemy trzecia, w pół do czwartej. Od czego zaczynamy dzień - jak ktoś wierzący, to się trzeba przeżegnać, no nie, to jest toko prowda. Resztę co? Kawę jak zdążą zrobić, to zdążą, jak nie, to nie, bo trzeba zaprzągać konia, trzeba jechać, bo se wozimy mleko koniem od owiec, bo trzeba podoić owce, doimy je tam, jak pani jechała, to widać koszor, nad drogą [...] $\mathrm{Z}$ wiosny doimy w sześciu, teroz to nos pięciu doi, szósty napędzo, a z wiosny w siedmiu. Trzeba napędzać, jak ich nauczy, to idą dobrze, to zależy od honielnika. Teraz doimy krócej, bo mniej mleka, ale na wiosnę to 2, 2 i pół godziny doimy, teraz w pół do 6 kończymy, po 5 nawet dwadzieścia ${ }^{21}$.

My wstajemy tak 4, 5 godzina. Na pocątku wiosny to 4 godzina, pierse se pijemy kawę, potem idziemy doić, a potem śniadanie, a w międzycasie tata grzeje mleko i robi tyn syr. Ja próbowałam doić, no bo rózne są sytuacje, tata nie da rady zawse doić, przyjechać coś, alebo cosic, doiłam, ale wam powim, ze mi dość dłuzej schodzi, cięzko jest, krowe podjim śmiało, bo ona stoi, przynajmniej stoi, a owce to sie pchają, to zaś baran sturchnie rogiem, trzeba ją dobrze trzymać, bo inaczej to zapalenie. Jedna osoba trzyma, a druga nagania. Latem tak wstajemy wpół do piątej, coraz to później. Jesteśmy tu od pocątku maja, do konca września, pół października ${ }^{22}$.

Sześciu nos jest, łącznie ze mną, bydła mamy przeszło 1400, krów prawie 50, wstajemy za piętnaście trzecia, już wyjeżdżom z domu, doić zaczynamy już dwajścia po trzeciej, doi pięciu, tam koło Chrześnicy ${ }^{23}$.

${ }^{20}$ U. Janicka-Krzywda, Magia hal i połonin [w:] Pasterstwo w Karpatach. Tradycja a wspótczesność. Szkice, red. M. Kiereś, Warszawa 2014, s. 47; E. Niculiţa-Voronca, Datinele şi credinţele poporului român adunate şi aşezate în ordine mitologică, Bucureşti 1998, s. 461-540.

${ }^{21}$ BT, wywiad z bacą Andrzejem Zubkiem, Dusztyn, sierpień 2017.

${ }^{22}$ BT, wywiad z Teresa Miętus, Polana pod Leśniczkówką (okolice Hali Śmietanowej), Zubrzyca Górna, sierpień 2017.

${ }^{23}$ BT, wywiad z bacą Bronisławem Leśnickim, Przełęcz Snoska, sierpień 2017. 
Wstajemy za piętnaście trzecia, ni ma pani lekko, za piętnaście trzecia już wyjeżdżom z domu, dwajścia po trzeciej już zaczynamy doić, doi pięciu, tam mamy stado koło Chruśnicy. Tak do szóstej nam zejdzie, tak do za piętnaście szósta, zależy jakie posłuszne są, jak spokojna, to idzie ${ }^{24}$.

Wstajemy o cwartej, dzień zacynamy od kawy, no tak robią, jak jest czas, bo jak przyśpią, to trzeba zabierać bornię na traktor i jechać ku owcom [...]. No wstają, zbierają się, albo piją kawę albo jadą ku owcom i zacynają doić. Ogólnie to jest icj siedmiu, jeden naganio, a seściu doi, dojenie to zalezy, trwo tak mniej więcej dwie godziny jak jest duzo mleka, duzo dojenia, jak się dobrze pasą, no bo jak jest tak sucho, sucha pora to tez trochę utna mleka, no nie, cy leje, desc jest to tyz ucinają, no teraz tak ogólnie doją do półtorej godziny, końcą przed sóstą ${ }^{25}$.

Ze względu na to, że życie pasterskie budzi współcześnie zainteresowanie dziennikarzy, turystów i pasjonatów tematu, a bacowie coraz częściej są pytani o „rozkład dnia", nierzadko budzi to już wśród nich śmiech, a także powoduje żarty z pytających. Bacowie zapytani o początek dnia i pierwsze wykonywane czynności odpowiadają:

Wszyscy się nos pytają od cego zacynamy dzień. Cy od dojenia cy od jedzenia. A my to zacynamy dzień od sikania, potem dopiero pijemy se kawe lub dojimy owce, prowda?

- Prowda, my to Pani od sikania zacynomy dzień, a jakzeby inaczej?26.

W tego typu rozmowach i żartach ujawnia się cała sfera specyficznej postawy, jaką przyjmują coraz częściej pasterze przed obcymi - z jednej strony jest to chęć rozmowy i udzielania informacji, z drugiej - dostrzeżenie powielania przez badaczy i turystów tych samych schemtów, które wciągnięte zostają w świat pasterskiego żartu, uwidaczniającego się w wielu sytuacjach na szałasach. Można powiedzieć, że jak w Bachtinowskiej ludowej kulturze śmiechu i tradycji karnawału, rządzą tu specyficzne reguły: odrzucony zostaje tradycyjny codzienny porządek hierarchiczny, a w jego miejsce tworzy się nowy - szałaśniczy; prawa i reguły stosunków międzyludzkich panujące na codzień ulegają zawieszeniu; elementy powagi przeplatają się z elementami śmiechu i humoru, które uwidaczniają się w wielu sferach życia pasterskiego ${ }^{27}$.

W zależności od liczby owiec i juhasów czynność dojenia trwa zazwyczaj od 2 do 3 godzin; wykonują ją na szałasach bacowie, podbacowie lub juhasi. Gdy baca jest w podeszłym wieku, a szałas nie posiada wielu pracowników zewnętrznych czynność tę przejmują młodsi, a baca zajmuje się naganianiem owiec, przysposobianiem sprzętu do wyrabiania serów lub przygotowywaniem posiłku, który nastąpi po dojeniu. Dojenie wykonuje się we względnej ciszy i spokoju, żeby nie niepokoić owiec, bo stres u tych zwierząt może odbić się na ilości uzyskiwanego mleka. $Z$ tego też powodu wielu baców pilnuje, aby nie było w pobliżu osób postronnych, ze względu na wzma-

${ }^{24}$ BT, wywiad z bacą Bronisławem Leśnickim, Przełęcz Snozka, sierpień 2017.

${ }^{25}$ BT, wywiad z Marcelą Plutą, bacówka na Trypsiance/Bacówka na Nowinach, sierpień 2017.

${ }^{26}$ BT, wywiad w bacami Jarosławem Buczkiem i Adamem Gruszką, podróż na Ukrainę, styczeń 2017.

${ }^{27}$ R. Bachtin, Twórczość Franciszka Rabelais'ego a kultura ludowa średniowiecza i renesansu, 1969. 
gający się niepokój zwierząt. Często dystansu między dojącymi a osobami chcącymi przyglądać się tej czynności strzegą pasterskie psy, które niechętnie dopuszczają obcych do kierdla. Pasterze rozpoczynają dojenie zazwyczaj od krótkiego skupienia i ciszy, podczas której wypowiadają słowa znanych modlitw lub modlą się własnymi słowami: ,odmawia się modlitwy, czy to zdrowaśki się mówi czy Ojcze nasz, jak kto se tak umie, to się modli" ${ }^{28}$. Zachowania te pokazują, że zarówno dawniej, jak i dziś, w świadomości wielu pasterzy istnieje przekonanie, że wszelka praca przez nich wykonywana powinna dokonywać się „z Bogiem”, bo bez niego nic nie może dokonywać się w świecie pasterzy ${ }^{29}$.

Podczas dojenia pasterze siadają w wyznaczonym do tego miejscu przy wejściu do koszaru, zwanym strungą, na małych drewnianych półkach, do dyspozycji mają również plastikowe lub metalowe ocynkowane wiadra, do których doją mleko. Zawartość wiader dojący lub osoby pomagające zlewają do kilkudziesięciulitrowej drewnianej puciery, czyli drewnianego naczynia (rodzaju beczki) wykonanego z deszczułek dębowych, przeznaczonego na mleko i przetwory mleczne, zbudowanego z klepek i dwóch metalowych obręczy, w której mleko będzie następnie klagowane i w której wyrabiany będzie bundz. Mleko zlewane jest przez bawełnianą szmatkę zwaną satą (szatą), czyli płótno do cedzenia mleka i zawieszania serów do ocieknięcia. Na szacie umieszcza się tzw. cetynkę lub jedlinę, czyli ścięte gałązki iglastych drzew, aby nazbierane podczas dojenia nieczystości (igły, owady, piasek) zostały wyłapane i nie przedostały się do mleka, z którego będą wyrabiane sery. Jest to przede wszystkim jodła (jedlina), ale można również używać gałęzi innych drzew. Taka praktyka wynika z przekonania o praktycznym znaczeniu jodły - na gęste, dość długie igły, którze dobrze filtrują nieczystości. Z drugiej strony, hermeneutyczne i semiotyczne analizy znaczeń związanych z tym drzewem są czytelne; w całych Karpatach jodła miała w wyobrażeniach ludowych niezwykłą siłę, jej właściwości apotropeiczne wykorzystywane były we wszystkich obrzędach i rytuałach przejścia (narodziny, zaślubiny, śmierć). Warto zaznaczyć, że niektórzy pasterze przywiązują do tej czynności dużą wagę, dbając o to, aby mleko służące do wyrabiania serów było bardzo czyste. Przy złej pogodzie (deszcz, błoto) mleko bywa przelewane kilkakrotnie, a szmatka kilkakrotnie prana. Podkreślają również, że wykonywanie tych czynności stanowi tradycję, której poszczególne elementy powtarzają się od wieków i są przenoszone drogą ustną w toku nauki pasterstwa na szałasach. Warto również zaznaczyć, że te same gesty są wykonywane przez pasterzy na całym pograniczu polsko-słowackim, na każdej bacówce. Również reguła ta dotyczy wykorzystania takich samych sprzętów i akcesoriów; takie zachowania pokazują, że tradycje te musiały uformować

${ }^{28}$ BT, wywiad z bacąAndrzej Zubkiem, Dusztyn, sierpień 2017.

${ }^{29} \mathrm{Na}$ takie wierzenia istniejące wciąż we współczesnym świecie pasterzy zwróciła uwagę Małgorzata Kiereś w materiałach zebranych podczas badań terenowych w Beskidzie Śląskich i Żywieckim, zob.: M. Kiereś, Wiosenne aspekty pasterskiej obrzędowości Górali Ślaskich - refleksja z badań terenowych [w:] Bacowie $i$ wałasi. Kultura pasterska na pograniczu polsko-słowackim, red. Ewa Kocój, Józef Michałek, Warszawa 2018, w druku. 
się bardzo dawno, w odległej przeszłości i wynikać z ukształtowanej wóczas profesji pasterskiej.

Przy końcu dojenia, przy ostatniej owcy przechodzącej przez okienko, osoba naganiające (zazwyczaj honielnik, ale czynność tę może wykonywać także juhas, a nawet baca) zobowiązany jest wypowiedzieć następujące słowa: dość u Boga wiać, które dla wielu z nich mają znaczenie magiczne - zapewniające dostatek mleka:

Po dojeniu, jak się doi trzeba sie przeżegnać, a po dojeniu człowiek znowu powinien się przeżegnać i jak ostania owca przechodzi przez okienko, to juhas goda «dość i Boga wiać» («dozi boga wiać») po mojemu to: Panie Boże przeżegnaj (no pobłogosław), od nieszczęscia zachowaj i nogoć jesce wiać (i jesce zeby było wiecej, jak Bóg da). Dozi to znacy, że już ostatnio, łostatnio [owca przeszła] i jeszcze zeby było więcej w przyszłości $i^{30}$.

Mówi się „,dość u Boga wiać”, to znaczy, że owiec jest juz dość tutaj, ale u Boga jest więcej, no nie, to się tak godo zawsze, a jesce potem baca się tyz modli, odpowiado. Bojtar, to jest taki pomocnik juhasa, ten, co naganio, ten, co jest w tych owcach i naganio i jak ostatnia owca przyjdzie, to godo „dość uboga wiac”, a baca tam radzi, odpowiado, tylko kurce nie pamiętom jak, bo oni se tak pod nosem cosik murczą i nigdy nie mogę zrozumieć. Potem się jesce baca przeżegno, tak na początku, jak i na końcu i hej ${ }^{31}$.

Starsi bacowie tłumaczą znaczenie tych słów wskazując na sakralny charakter swojej pracy, która według nich zawsze całkowicie zależała i wciąż zależy od woli Boga. Jednocześnie uczestniczący w dojeniu bacowie wypowiadają po cichu pacior$k i$, czyli modlitwy, w których dziękują Bogu za udany udój mleka. Do obowiązków juhasa lub bacy należy wygłoszenie tradycyjnej odpowiedzi: Panie Boże przeżegnaj, od nieszczęścia zachowaj i nagoć jeszcze wiać lub ,Panie Boże przeżegnaj, od złego zachowaj i nagoć mleka wiac. Współcześni pasterze znają bardzo dobrze te słowa i wypowiadają je co najmniej 2 razy dziennie, jednak wyjaśnienie ich sensu znają zazwyczaj tylko starsi doświadczeni bacowie, młodszym pasterzom przychodzi ono już z trudem. Mają oni świadomość sakralności i ważności owych słów, przekazywanych im przez starszych jako tradycja, ale powtarzają je często mimowiednie, trochę jak zaklęcia, co wynika prawdopodobnie z częściowego zagubienia istoty wypowiedzi.

Po zakończeniu dojenia baca lub wyznaczona przez niego osoba klaga mleko zlane do puciery. Proces klagania to w rzeczywistości proces ścinania mleka podpuszczką, dawniej naturalną, pozyskiwaną z żołądków zwierząt, obecnie kupowaną jako substancja czynna w sklepach. Po jej wlaniu do mleka i przykryciu puciery, po około pół godziny mleko zaczyna się ścinać. Wyrabiający sery rozstrzepuje dokładnie owo ścięte mleko drewnianą felurą - rodzajem łyżki z dziurami, co powoduje, że w mleku pojawiają się drobne, ale równo rozprowadzone kawałki sera. $\mathrm{W}$ tym czasie pasterze mają krótki moment spokoju, który wykorzytują zazwyczaj na poranny posiłek, któ-

${ }^{30}$ BT, wywiad z bacą Andrzejem Zubkiem, Dusztyn, sierpień 2017.

31 BT, wywiad z Marcelą Plutą, żoną bacy, lat 28, bacówka na Trypsiance/Bacówka na Nowinach, sierpień 2017. 
ry najczęściej składa się z chleba, kawałka kiełbasy, boczku oraz kawy lub herbaty. Wielu z nich je wyłącznie mięso i wędliny pochodzące z własnego uboju - nie mają zaufania do produktów mięsnych kupowanych w sklepach. Z tego powodu na szałasy zabierają wyroby, które przygotowali wcześniej we własnych gospodarstwach. Większość pasterzy zgodnie twierdzi, że czasu na jedzenie zawsze brakuje:

Jedzenie to jest tak na ostatnią chwilę. Pierse trza pozdajać, zaklagać, zjeść i siadać ku oscypkom,
jak się robi oscypki. Jak się ugotuje, to się je, to zupę jaką, czy tam mięso jakieś, zupę jakąś, dziś mo-
zna w sklepie byle co kupić, bo jest wsystko, kupujemy bocki, nie bocki, kiełbasę, to się je, co sie je
w chałupie, niedawno to na sałasie była ino słonina, smolec był, chleb, w Biescadach mlecarnia przy-
woziła, bot am do sklepu było daleko, tot am nikt nie szedł, jak ino mlecarnia dowoziła, jak sięod-
dawło mleko, to się zamawiało chleb, jedzenie, tot am przywozili, przewaznie słonina była i smalec,
kawy nie było, cukru nie było, nie było nic. A teraz! Na obiad to se upieką kiełbasy czy se zupę ugo-
tują, przy oscypkach jest cas ugotować, np. baraninę, tu dziś nasi gotowali baraninę ${ }^{32}$.

Śniadanie jedzą jak zdążą, jak się klaga, jak zdążą, no bo trzeba jeszcze drzewo przynieść ku palenisku, trza pomyć te bornie, trza iść ku świniom, no różne rzeczy, no różne rzeczy trzeba jeszcze zrobić, no to jak zdążą, to zjedzą, no a jak nie, to dopiero po robocie, tak koło dziesiątej, jedenastej. Co jedzą? No usmazą se casem jajecnicę na bocku, albo te kiełbasę se uwarzą czy upiecą na ogniu. Oni to tak musą tyz patrzeć, zeby to wartko było, casami to kanapkę chycą czy chleb, kanapkę i kiełbasę do ręki, no i tylo, bo zaś trzeba na pierwsą doic ${ }^{33}$.

Śniadania, pani, to ni ma czasu jeść, jemy w trakcie, jemy co jest, kiełbasę, mamy tu kuchenke gazową, wszystko jest, chleb, oscypków i bundza nie jemy, bo jak sie robi z tym, to juz ni ma smaku, coś innego się chce ${ }^{34}$.

Po dojeniu i śniadaniu przychodzi czas robienia serów. Sery robi zazwyczaj baca, a gdy mleka jest dużo, pomagają mu często wyznaczeni do tego juhasi. Gdy bacy nie ma na szałasie (co oznacza, że wyjechał w sprawach służbowych), sery wykonuje tzw. podbaca, czyli osoba wyznaczona przez bacę na jego zastępstwo. W prawie każdej bacówce wyrabia się obecnie oscypki, sery gazdowskie (gołka, pucok, kara), redykołki, bundz i bryndzę oraz słodką i kwaśną żentycę. Dwóch baców - Piotr Kohut z Koniakowa i Jarek Buczek z Ochotnicy Górnej - wyrabiają teżw Polsce tzw. ser wołoski, czyli twardy, dojrzewający, okrągły ser (wciąż bardzo popularny wśród pasterzy rumuńskich) ${ }^{35}$. Do wyrabiania serów pasterze wykorzystują różne formy, które ułatwiają im nadawanie serowi odpowiedniego kształtu. I tak np. uformowany ser na bundz wkładany jest jeszcze w pucierze do dużego kawałka do szmatki (pieluchy), która jest zawiązywana na czterech końcach i zawieszana na felurze nad pucierą. Powoduje to, że bunc ocieka i pozbywa się nadmiaru serwatki, ale i nabiera również specyficznego okrągłego kształtu. Ci pastrze, którzy dodają do niego przypra-

32 BT, wywiad z bacą Andrzejem Zubkiem, Dursztyn, sierpień 2017.

${ }^{33}$ BT, wywiad z Marcelą Plutą, żoną bacy, lat 28, bacówka na Trypsiance/Bacówka na Nowinach, sierpień 2017.

${ }^{34}$ BT, wywiad z bacą Bronisławem Leśnickim, sierpień 2017.

${ }^{35}$ Ekonomika gospodarki pasterskiej ,Sałasz”, b.a, b.m.w., s. 30-42. 
wy (np. czosnek niedźwiedzi), aby podnieść walory smakowe buncu wkładają go dodatkowo do metalowej formy w kształcie prostokąta, gdzie mieszany jest z ziołami i pozostawiany przez jakiś czas do uformowania i nabrania walorów smakowych. Po określonym czasie ser jest wyciagany z formy i sprzedawany. Z kolei oscypki wykonywane są w drewnianych prostokątnych formach, które od strony wewnętrznej są rzeźbione i mają kształt owalny. Baca wkłada odsączony bunc do formy, zamykając ją mocnym zaciskiem, co powoduje, że ser nabiera kształtu wewnętrznego rzeźbienia formy. Po odciśnięciu i odleżeniu forma jest otwierana, czyli rozszczypywana (stąd nazwa sera - oscypek), a ser umieszczany nad płonącym dymem ogniska do wędzenia. Każdy z baców przy wyrabianiu serów przestrzega tradycji, ale stosuje także swoje własne sposoby na jego smak:

Mleko przywozimy, od razu cedzimy. Śniadanie jemy, jak przecedzimy, ono [mleko - EK] się tam klaga, a w tym casie jemy śniadanie, jemy różnie, najceściej kiebłasę z chlebem, ale różnie, gotujemy se. Zlewamy do puciery, robimy syr, bundz lub oscypki. Sposobu robienia za dużego ni ma, musi być podpuscka, świeze mleko musi zaklagać, a później ręcnie, albo zbieramy syr ręcnie, oscypki nabiermy do cerpaka. Na syr to nie podgrzewamy mleka, ale jak na oscypki to troske trza, podgrzewa się do tego stopnia mleko jak prosto od udoju, poznajemy na wyczucie, dotykamy. Podrzgewa sie w kotle nad ogniem, później się wlewa do tego podpuszczke, w pucierze, po pół godziny jest sklagane i wtedy rozstrzepuje sie ten syr na drobno, w pucierze taką felurę na drobno, żeby nie było twordo, później jak na syr to zbieramy, wyciskamy tak zeby podłożyć tą szatę, nie tak jak babcie cedzą, my podkładamy i wyciągamy w całości. Później dopiero ocieka, ale my ugniatamy ręcznie, jak cała puciera mleka podejdzie to nie ma do czego przelać, to całe naczynie, nie mieści się i z tego wychodzi bundz. Jak robimy bryndzę, to wtedy robimy jak bundz jest niedosprzedany, z tego syra robimy bryndze, musi być syr starszy, ze swiezego się nie da, mielemy, teraz już masynka elektrycna w domu mielemy, salimy, mozna już od razy sprzedawać. A oscypki to nie kładzie sie saty, tyz trza ugniesc, ale sie juz nie kladzie saty, ino sie nabija do cerpoka, w pucieze, formuje sie takie kowołki, to się wyciąga, takie buły z tego całego sera, ile się nabije tych buł, no to tyle i później się ugniata w ciepłej wodzie w kotle, w takiej wodzie, co się da ręke włozyc, a ciepło musi być, stopniowo, z pół godziny, później jak już czuje sie, że ni ma w sobie syrwatki ani wody, jest taki miękki, elastyczny, ze się nie potardze, to się daje formę, nakłada się wzorek, nakłąda sie wzorek, ale stożek oscypka wyrabia się ręcznie, takze forma jest tylko na wzór, ale na kształ to się ręcznie. Potem się go jeszcze soli 24 godziny, poźniej suszy się 24 i wędzi, to zalezy od pogody, jak jest drzewo mokre, to się szybciej uwędzi, no tak 3 do 5 dni się do wyrabia. Oscypek sie wędzi dymem, nie trza temperatur ${ }^{36}$.

Pierwse trzeba podoić, odcedzić, taką cetynkę się daje na, satę, powązkę, no i później grzejemy mleko nad watrą, do puciery się daje, tak delikatnie się podgrzewa, później się daje do puciery no i daje się podpuscke, jak jest zimno to się dużej ścina, jak ciepło, to szybciej, wszystko zależy na bacówce od pogody, nawet humor, nawet owiec i tych wszystkich co pracuja przy tym. Jak jest zaklagane, to taki skrzep się robi, jego się potem przecina, no i tak, i krzyż się robi, żeby się udało, no i później się rozbija ten skrzep, zostawia się na chwilkę, zaś niedługo, na chwilę, zbiera się do takiej saty, takiej gazy i to jest bundz, wiesza się na kiju i obcieka. Gołki - nie zbiera się tego sera, ino się nabiera do cerpaka i robi się takie kulki, trzeba zagrzać żeby to byłą gorąca woda do tego, żeby to ognieść, fajnie, żeby to było gładkie, przebić, forma musi być, taką formę drewnianą sie bierę, zakłada, wyciskuje i taka fajna gołka wychodzi, daje się do zminej wody i potem do rosoły, do wody z solą. Bryndzę zaś, jak bundz zostanie, jak posiedzi tak to zależy od pogody, bo jak jest zimno, to tak nie

${ }^{36}$ BT, wywiad z bacą Janem Hyrczykiem, Baligówka (Czarny Dunajec), sierpień 2017. 
skwaśnieje szybko, jak jest cieplej to skwaśnieje szybciej i zrobią się takie dziurki w środku, rozgniata się go, soli, na drugi dzień zamieszo i no i bryndza dobra jest nawet dobra jest ze szczypiorkiem, naprawdę 37 .

Po zakończeniu wyrabiania serów wszystkie używane naczynia są myte ciepłą wodą, a następnie odstawiane do wyschnięcia. Wielu pasterzy dba również o to, żeby przechowywać je w czystym miejscu, tak by nie uległy zabrudzeniu wskutek kaprysów pogody albo przez zwierzęta czy ludzi i by nie trzeba ich było ponownie myć przed kolejnym użyciem. Ogólnie współcześni pasterze przywiązują zazwyczaj dużą wagę do czystości wyrobów mlecznych, całego szałasu i sprzętów na nim używanych. Wynika to przede wszystkim z tego, że zmieniła się świadomość pasterzy w tym zakresie, a także z nowych przepisów związanych z realizowanymi w Polsce unijnymi projektami, które jasno określają zachowania pasterskie i możliwości wyrobu i zbytu produktó $w^{38}$. Pasterze są z nimi zaznajamiani dzięki uczestnictwu w specjalnie zorganizowanych dla nich szkoleniach. Ponadto, współczesna mobilność samych pasterzy powoduje, że wielu z nich odwiedza się na szałasach, a informacje o niegospodarności i nieczystości któregoś z nich, szybko stają się powszechną tajemnicą.

\section{PRZEDPOLUDNIE}

Po wyrobieniu serów i porannym posiłku przychodzi moment „względnego odpoczynku" na szałasach. W tym czasie juhasi wraz z honielnikami wyruszają na wypas, udając się na okoliczne hale, gdzie będą przebywać - w zależności od liczby dojeń na szałasie (dwóch lub trzech) - do obiadu lub do wieczora:

wceśniej te owce już idą, bo jedni zostają w kolebie, a dwóch idzie paść, zostają w kolebie i robią właśnie te oscypki i tam wsyśko przygotowuje, a tych dwóch cały czas, codziennie idzie paść. I oni własnie jesce godzinę po dojeniu trzymają w koszorze i za ten cas se idą jeść, pojedzą i potem wychodzą z owcami do pasienia, popaść tak do pierwsej godziny i potem zaś na pierwsą do kosoru zganiają owce, a ci z koleby jak se już pojedzą, posprzątają, to idą na pierwsą doić. No i powtórka z rozrywki, trzy razy się doi jesce teraz, tak o ósmej jesce, o dziewiatej, tyz zalezy, jak zbierają syr, to końcą o jedenastyj, a jak nie zbierają sera, to tak dziesiąto, pół dziesiątej ${ }^{39}$.

Niektórzy pasterze zabierają ze sobą zazwyczaj trochę pożywienia - chleb, kawałek kiełbasy lub sera, do tego piwo lub wodę. Większość juhasów wypasających stada stosuje system sygnałów i zawołań pasterskich o prostej melodii, które pozwalają im dobrze kontrolować stada, w tym gwizdy (różnej długości), sygnały dawane rękami

${ }^{37}$ BT, wywiad z Teresą Miętus, Polana pod Leśniczkówką (okolice Hali Śmietanowej), Zubrzyca Górna, sierpień 2017.

${ }^{38}$ Ekonomika gospodarki pasterskiej ,,Sałasz”, b.a, b.m.w.

${ }^{39}$ BT, wywiad z Marcelą Pluta, żoną bacy, lat 28, bacówka na Trypsiance/Bacówka na Nowinach, sierpień 2017. 
i ciałem, krótkie okrzyki, komendy, przekleństwa. Dla ich wzmocnienia pasterze wykorzystują też drewniane laski lub tzw. pręć lub chabinę - witkę lub cienki kij służący do poganiania owiec i sterowania nimi ${ }^{40}$. Pręcie są zazwyczaj wykonane z gałązek wierzbowych, często kwitnących i zakończonych zielonymi liśćmi. Pasterze opierają się też na pomocy psów, które są szkolone do tej pracy od najmłodszych lat. Podobnie jak owce, psy uczone są reagowania na gwizdy, sygnały wykonywane rękami i ciałem oraz dodatkowo komendy typu „góra”, „dół”, „lewo”, „prawo”, „przód”, „ty1"41. Doświadczone i odpowiednio wyszkolone psy trzymają się w stosunku do owiec w określonej przestrzeni - na czele (prowadząc wraz z pasterzami kierdel i bacząc na niebezpieczeństwo z przodu), z tyłu (za stadem, a nawet w pewnej odległości od niego, zamykając stado i zwracając uwagę na niebezpieczeństwo z tyłu i z boku) oraz po bokach. W momencie rozerwania szyków przez kierdel czy niespodziewanych zwrotów owiec $\mathrm{w}$ niewłaściwą stronę, psy z przedniej lub tylnej przestrzeni potrafią podbiec i wspomóc pasterza w zaganianiu owiec. Owce i nowe psy szybko uczą się tego typu sygnalizacji -już w drugim dniu przebywania na szałasach przy doświadczonym juhasie znają większość sygnałów i starają się do nich stosować; starsze pamiętają je z poprzednich lat. Powszechnie uważa się, że pasterze używają do pracy z owcami przede wszystkim owczarków podhalańskich. Współczesne badania pokazują jednak, że wielu pasterzy wykorzytuje również często psy wielorasowe lub border colie, które w przekonaniu wielu pasterzy dobrze radzą sobie na halach, gdyż są szybkie, zwinne, chętne do wykonywania poleceń i nastwione na pracę z człowiekiem i nigdy się nie męczą.

Po wyrobieniu sera, bacowie i pasterze pozostali na szałasach, zazwyczaj oczekują na nabywców swoich wyrobów - w tym czasie odwiedzają ich zazwyczaj mieszkańcy górskich regionów, którzy w sezonie pasterskich przybywają z okolicznych miejscowości, aby nabyć świeże sery i żentycę, jak również turyści i przejezdni. Dużą grupą zakupującą sery są turyści, którzy w sezonie wypasu przybywają do bacówek i kupują je bezpośrednio u baców. Są to przede wszystkim turyści polscy, ale zdarzają się również stali odbiorcy, którzy chętnie zatrzymują się zwłaszcza przy dogodnie położonych szałasach i dokonują zakupów (m.in. Baligówka k/Czarnego Dunajca, Dolina Chochołowska, Dolina Kościeliska, Kuźnica, Kalatówki, Bacówka na Szańcach w Koniakowie, Dolina Chochołowska, Polana Szymoszkowa, Brzegi, Sromowce, Łapsze Wyżne, Wetlina). Wśród odbiorców są również pasterze, którzy wyemigrowali do Stanów Zjednoczonych i przyjeżdżają okresowo do Polski, aby odwiedzić swoje rodziny:

do Ameryki duzo idzie oscypków, przyjezdzają na wakacje z Ameryki, duzo nawet takich ludzi przyjezdza, co juhasili, moze tam juz ni ma takich co bacowali, bo juz nie zyją, ale byli tacy downiej co bacowali i wyjechali do Ameryki, jak przyjechal tu, to chciol ino oscypki, teroz tak samo, cóz tam

${ }^{40}$ Por. W. Herniczek-Morozowa, Terminologia polskiego pasterstwa górskiego, cz. I, Warszawa Wrocław - Kraków - Gdańsk 1975, s. 150.

${ }^{41}$ BT, wywiad z Magdaleną Chrząszcz, Jeleśnia, kwiecień 2018. 
powiezie do tej Ameryki, jedynie oscypek, cy tam bryndze casem, prózniowo pakujemy, czy bryndze nawet bierą se, nawet i żentycę bierą. Kiesik se tu zamówił, godo, ze se przewiezie zentycę do Ameryki. Jest duzo góralskich ludzi w Ameryce, co to jedli i robili z tym, chcą jesce tam spróbować 42 .

Niektórzy bacowie mają odbiorców wśród miejscowych gazdów, którzy zakupują sezonowo sery, aby oferować je turystom jako dodatek do wykupionych przez nich w ich gospodarstwach posiłków. Inni odstawiają również sery do okolicznych punktów sprzedaży, własnych lub tych, których właściciele zakontraktowali dostawy od nich. Coraz częściej bacowie mają dwa lub więcej punktów sprzedaży produktów mlecznych:

\begin{abstract}
Sprzedajemy tu i jesce na Sromowcach, tam Darka żona ma taki pukt handlowy, tam jest taki pasaż handlowy, to ona tam ma swoje stoisko, tu sprzedajemy codziennie w sezonie, w zimie juz nie stoimy ani tam, ani tu. Zaopatrują się turyści, ale i miejscowi, bardzo duzo miejscowi, tak bym powiedziała, że pół na pół. I tez jest potem duzo takich, co tu na wakacje zjezdzo, no i potem do Ameryki lecą, no to tyz duzo zamawiają, musimy ofoliować, bo tyz juz momy foliarkę, not o oni nie musą potem jeździć ofoliować, a wsyśko w jednym miejscu, bierą naprawdę niektórzy duzo bierą, no bo jak ma rodzinę taką więksą i może se pozwolić, zeby wziąć w bagaż, bot o wiadomo, potem tyz wazy trochę, nie, te sery, wsyćko, i kostuje trochę, takze bierą, bierą. Tam tyz niby robią oscypki, ale na pewno nie takie, takze bierą ${ }^{43}$.
\end{abstract}

Przed południem ponadto pasterze gotują dla siebie i swoich pracowników ciepłe posiłki, które zjada się - w zależności od rozkładu dnia oraz liczby dojeń i czasu wypasu - wczesnym popołudniem lub dopiero wieczorem, jako obiadokolację. Pilnują również wędzenia serów i przegradzają koszary:

Potem trza iść poprzekładać na półki, sery takie i takie, zeby równo się wędziły, inni idą ku koszarze, trza koszor przegrodzić, jedne juz posedł, dwóch posli z owcami, jesce z krowami. Południe przyjdzie, trzba podoić, o drugiej zaś doimy, przed doimy jemy obiad, sami se robimy, sami gotujemy, a kto nam pogotuje? Tu momy kuchenke, gotujemy co nom pasuje, wsystko pani umiem ugotować, a co to jest, a jak na Biescadach sie jest cy gdzie, wsystko trzeba umieć, a jak w Ameryce, to kto bedzie gotowoł? Dziś barana bedziemy ino ważyć. Czosnek damy, sól, potem gotujemy, przypiec tyż można ${ }^{44}$.

Na bacówce jedzenie jest proste, bo nie ma czasu na robienie czegoś skomlikowanego; bacowie podkreślają, że proste jedzenie, do którego przywykli od lat, najbardziej im smakuje. Na obiad gotują często żur na żentycy albo rosół, jedzą, jak już wspomniano, kiełbasę z chlebem i baraninę (czasem jagnięcinę, ale tę rzadziej). Gdy bacówki są położone w bliskiej odległości od domu, zadarza się, że obiad przywożą im z domu matki lub żony. W wyjątkowych wypadkach kupują obiady we wsi w knaj-

${ }^{42}$ BT, wywiad z Andrzejem Zubkiem, Bursztyn, sierpień 2017.

${ }^{43}$ BT, wywiad z Marcelą Plutą, żoną bacy, lat 28, bacówka na Trypsiance/Bacówka na Nowinach, sierpień 2017.

${ }^{44}$ BT, wywiad z bacą Bronisławem Leśnickim, sierpień 2017. 
pie i przywożą na szałasy - tak bywa zazwyczaj wówczas, gdy załatwiają różne sprawy w pobliskich miejscowościach:

Później se gotujemy, zupy, rosół czy tam co, juhas idzie z owcami o siódmej, przychodzi tak na piersą, główna polana jest tam, ze 2 kilometry, pasie tam i przychodzi z powrotem, my w międzyczasie gotujemy, róznie jemy, czasem kupimy ze sklepu, np. udka kupimy, mięsa mamy baraninę, jagnięcinę, ino ze mięso w domu mamy, przywieziemy se, ugotujemy nad paleniskiem, w drugim sałasie, tam gotujemy, zupy tyż gotujemy, naucyłem się na bacówce gotować, w domu nie gotuje, czasem nam przywiozą obiad, teraz częściej, bo blizej, dawniej tam nie było, wszystko se gotowali sami na sałasie, np. Na Orawie to tam nie przywozili. Duzo gotujemy na zentycy, barszcz czy zurek, na zentyce i wodę pół na pół, ziemniok, marchew, pietruszka, kiełbasa, zasmażka ze słoniny, żeby było tłuściejsze, białą kiełbasę. Baraninę nad ogniem pieczemy, kawałki, nie całego barana, czosnek trzeba dać, dużo czosnku, musi być baraninę czuć, a ryby nie czuć, kobietę też trzeba czuć, nie tylko perfumami, jagnięcinę też trzeba na ogniu upiec, bardzo pyszne jedzenie, ziemniaczki do tego, surówka, ni ma lepszego jedzenia ${ }^{45}$.

Kawałek kiełbasy nawet, jak jest zentyca to nawet barsc mozna ugotować, ziemniaków, dajemy, bardzo dobry barszc jest na zentycy, a jak zentycy nie ma, to ino kawałek chleba z kiełbasą się zje, róznie jest, ni ma co grymasić, przede wszystkim kawa musi być, kawę na kuchence gotujemy ${ }^{46}$.

Około godziny 12-13 (zależy to od zwyczajów panujących na danej bacówce), ci pasterze, którzy zachowują zwyczaj trzykrotnego dojenia owiec w ciągu dnia, wracają ze stadami na szałas. Owce są tu dojone, ponownie robi się sery, a juhasi i honielnicy zjadają obiad, po czym wyruszają po raz trzeci ze stadami na wypas na hale, wracając z nimi wieczorem, około 18-19 godziny. Niektórzy bacowie doją je wówczas po raz trzeci raz - kończą tę czynność około godziny 21-22:

Po obiedzie doimy drugi raz, tak o 3, i po dojeniu idzie juhas znowu paść, a my robimy syr. Pasą się do nocy, do dziewiątej, pasą się, ile chcą, jak same schodzą, to dość, tak teraz koło dziewiątej, wtedy same schodzą do koszora, wtedy zamykamy, śpią w pastuchu, a doimy w koszorze, to jest połączone. Po dojeniu mówimy modlitwy, honielnik gada dość uboga wiać, to jest takie na każdej bacówce, dość uboga wiać, no nie wiem, czy to jest mleko, czy co, trudno mi jest przetłumaczyć to słowo, czy to jest mleko, czy co, jo to znam z juhasów, z baców, niejeden sie mnie pytoł, ale dokładnie nie wiem co to $z$ naczy ${ }^{47}$.

\section{POPOŁUDNIE, ZMIERZCH I NOC}

Około połowy sezonu pasterskiego owce mają coraz mniej mleka, stąd też większość pasterzy przechodzi już na system dojenia podwójnego (około połowy sierpnia).

45 BT, wywiad z bacą Janem Hyrczykiem, Baligówka (Czarny Dunajec), sierpień 2017.

${ }^{46}$ BT, wywiad z Teresą Miętus, wywiad, Polana pod Leśniczkówką (okolice Hali Śmietanowej), Zubrzyca Górna, sierpień 2017.

47 BT, wywiad z Teresą Miętus, wywiad, Polana pod Leśniczkówką (okolice Hali Śmietanowej), Zubrzyca Górna, sierpień 2017. 
W sierpniu część baców wpuszcza już także barany do pokrywania owiec, aby młode jagnięte rodziły się wczesną wiosną i zakontraktowane - mogły zostać sprzedane:

\begin{abstract}
jak się dobrze owce doją, to lekcej się doi trzy razy, wtedy ręce ni mają takiego, to nie jest lekko robota, bot o trzeba wzburzyć i ręce puchną, na pocatku, no bo to jest wysiłek. Ni ma znacenia pogoda, to chodzi ino o owce, jak jest sezon, to się lepiej doi tryz razy, mają duzo mleka, wtedy się lekcej doi. Mleko się zmienia, zmienia się, własnie teroz mimo tego, że dużo leje, duzo grzeje, mimo tego że przechodzą przez potocek, to one tez tak utna to mleko, ale potem to one wracają do normy, ale casem to mleko to juz tak zostaje, no nie, no i jak potem juz ubędzie tego mleka, to juz doją dwa razy dziennie, ale to już zazwyczaj jest, jak puscają barany. A puscają barany tak na pewno nie wceśniej niż w połowie sezonu, czyli po 3, 4 miesiącach wyjścia na bacówkę ${ }^{98}$.
\end{abstract}

Dwukrotny system dojenia stad powoduje, że wydłuża się czas przebywania juhasów z kierdlami owiec w ciągu dnia na halach - przychodzą oni ze stadami do szałasów zazwyczaj pod wieczór, spożywając wówczas ciepły wieczorny posiłek. Tuż przed zmrokiem rozpoczyna się również wieczorne dojenie owiec, które trwa od 2 do 3 godzin, a po nim wyrabianie serów. Pasterze jedzą też kolację, która zazwyczaj składa się z tego, co śniadanie, lub też - w przypadku gdy w ciągu dnia przypadają dwa dojenia $-z$ ciepłej obiadokolacji ugotowanej w ciągu dnia.

Między godziną 21 a 24 pasterze udają się na spoczynek. Długość ich snu zależy od ilości owiec w stadzie i ilości dojeń przypadających w ciągu dnia. Współcześni pasterze śpią w różnych przestrzeniach - najczęściej w szałasach, które posiadają w zależności od ich projektu architektonicznego - dodatkowe pomieszczenia przeznaczone do różnych czynności, m.in. do dyspozycji bacy. Są one umieszczone z tyłu bacówki lub też wydzielone specjalną drewnianą ścianą z drzwiami, odgradzając tym samym przestrzeń do spania oraz wytwarzania i sprzedaży sera. Część pasterzy śpi w dodatkowych budynkach, które znajdują się przy szałasach. Są to zazwyczaj stare domy (jeśli szałas znajduje się na terenie starego, wykupionego lub wydzierżawionego przez bacę gospodarstwa, np. bacówka na Marysinej Polanie w Winiarczykówce na Orawie lub bacówka Pod Twardą Skałą w Dursztynie na Spiszu). Pasterze muszą również rezygnować z niektórych zwyczajów na szałasach, bowiem nowo wprowadzane przepisy sanitarne związane $\mathrm{z}$ prawem unijnych zakazują noclegu $\mathrm{w}$ przestrzeni szałasu służącej do wyrabiania i sprzedawania produktów mlecznych. $Z$ tego powodu niektórzy bacowie posiadają obecnie dwa szałasy, jeden z nich służy wówczas zazwyczaj do przetwarzania mleka i wyrobu serów, drugi - do spania (szałasy w Soblówce na Żywiecczyźnie):

dwie osoby śpią przy owcach, reszta na bacówce, mają tam taką osobną izbę, tam mają łóżka, pościele są ${ }^{49}$.

48 BT, wywiad z Marcelą Plutą, żoną bacy, lat 28, bacówka na Trypsiance/Bacówka na Nowinach, sierpień 2017.

${ }^{49}$ BT, wywiad z Marcelą Plutą, żoną bacy, lat 28, bacówka na Trypsiance/Bacówka na Nowinach, sierpień 2017. 
Szczególną porą w dobowym cyklu jest dla współczesnych pasterzy noc. Część z nich ze względu na stada, musi czuwać i ochraniać zwierzęta od potencjalnych niebezpieczeństw na nie czyhających. $Z$ tego powodu owce są pilnowane przez pasterzy przez całą noc. Zajmuje się tym baca lub wyznaczony przez niego juhas, który śpi obok owiec. Pilnujący śpi w tzw. budce (reg. kolibka, kucia), czyli przenośnej, wykonanej zazwyczaj z drewnianych desek szopie, zaopatrzonej w daszek i służącej pasterzom za nocny schron. Do środka pasterze wkładają siano lub materace, na których umieszczają kołdry lub koce do przykrycia nocą:

Jedni śpią na sałasie, a dwóch śpi przy owcach, mają takie budki, co jest ino materac włożony, do spania jakieś półecki mają na takie podręcne rzeczy i tam spią, no musi ktoś przy owcach spać ${ }^{50}$.

Śpimy na sałasie, tata przy owcach, on inacej nie umie i nie da nikomu spać przy owcach. Tak jest naucony, w sałasie, godo, ze się nie wyśpi. Owiec trzeba pilnować, od wilka, niedźwiedzia, mogą się przestrasyć tyż cegoś, zerwać 51 .

Budka ma prostokatny otwór, przez który pasterze wchodzą do środka, umożliwiający im również doglądanie zwierząt. Budkę umieszcza się w pobliżu koszara, tak by pasterze jednocześnie byli blisko owiec i mogli zmierzyć się z niebezpieczeństwem ze strony dzikich zwierząt. Coraz częściej pasterze czuwający w nocy nad stadami śpią w przyczepach kempingowych, które przywożą na początku sezonu pasterskiego i stawiają na halach. Przechodzenie stada na inne miejsca powoduje, że przyczepy są przeciągane i stawiane w nowym miejscu, obok koszarów.

Największym wyzwaniem nocy dla pasterzy są wilki i niedźwiedzie, które co rok na pograniczu polsko-słowackim atakują stada owiec. Drapieżniki te są spotykane na całym pograniczu, zarówno w Bieszczadach, Beskidzie Niskim, Sąddecczyźnie, Spiszu, Gorcach, Podhalu, jak i w Beskidzie Żywieckim oraz Śląskim:

W nocy pilnujemy owiec, tatuś śpi praktycznie przez całe lato, łon śpi, gado, że nikomu przy owcach nie da spać, bo my mieli taką sytuację jedną, jo chodziła do podstawówki, nie, jak była w gimnazjum, mielimy takiego juhasa świętej pamięci, taki szczupły, kurzył starsznie, kurzył do północy, a po północy spał jak prawie zabity, no i tak, w bacówce my spali, mama godo, zostaw że go, niechże się uczy, po to go momy, żeby nam pomógł, żeby tatuś spał w bacówce, a on przy owcach, i to tak było: rano czwarta godzina wstajemy, owiec ni ma w koszorze, przylecioł ten juhas i godo Bolek ni ma owiec, jednak owca zjedzona w koszorze, a prawie 20 owiec rozstrzepanych, a reszta tam w kąt, wilki, tauś powiedział koniec, on już nikomu nie da spać przy owcach. Teraz nawet w dzień wilki chodzą, w tamtym roku, one są tak cwane, jo tu byłam akurat sama z tatą, bo chłopcy byli w szkole, rano jok chciałam dosprzątać i tatus zaraz tam cekał, on mi godo posprzataj, przyjdź ku owcom, ja pojadę do chałupy, bo tam mioł też siano, trzeba wszystko przygotować na zimę, no dobra, poszła, on ino nawrócił auto i pojechał tu kawałecek, jo patrze wilki, dawaj dzwonię szybko do niego, na drodze ni ma zasięgu, normalnie wilk mi wylecioł z lasu, cekoł na to, żeby tatus odjechoł, odjechoł, bo wiedział, że ja ino przyjde abo nie, zacełam sie rozdzierać, ani petard nie miałam koło siedzieś. Dzwonię do taty, tato wilk wylecioł z lasu, tato godo żartujes, nie zartuje, południe już prawie było, tata przy-

${ }^{50}$ BT, wywiad z Marcelą Plutą, żoną bacy, lat 28, bacówka na Trypsiance/Bacówka na Nowinach, sierpień 2017.

${ }^{51}$ BT, wywiad z podbacą Stanisławem Szczechowiczem, redyk wiosenny, kwiecień 2018. 
jechoł, posiedzioł ze mną, i ten skurczybyk nie przylecioł, tata potem pojechał i on juz nie wyseł. Puścili my tę lepszą sukę i odegnała go ${ }^{52}$.

Współcześni pasterze podkreślają też, że sen jest często przerywany z powodu różnego zachowania zwierząt - potrafią one wyjść z koszara i rozejść się na różne strony, w przypadku niebezpieczeństwa ze strony dzikich zwierząt lub silnego wiatru wpadają też w panikę:

nie tak duzo śpią, jesce jak się pośpi, no bo jak zacynają wybudzać, czy owca czy krowa wybudzają, no bo czasem owca czy krowa wychodzą z pastucha, no to trzeba iść za nimi, no to masz po spaniu, no nie, czy owce tyż nie raz wyszły z koszaru, owce są takie, że one se same robią strach, że chybnie jedna, not o wsyćkie chybą, no i lecą jak głupie, not o potem trzeba iść za owcami. $Z$ wilkami nie było w tym roku jesce problemu, odpukać, roz, dwa roki temu, akurat my doili na południe, no to przelatywał, to tak kawałecek, pzelatywał niedźwiedź, my myśleli, że sarna, psy straśnie brechały, ale nie poszły, jeden sie tak pobroł, ale w połowie drogi sie zawrócił, tak jakby sie przestraszył, dopiero potem my widzieli po korze, jak tot am były rozwalone korzenie drzew i takie rózne rzeczy, not o sie domyśleli, że to był jednak niedźwiedź, ale to młody, to ino przechodził, tak se przelatywol, nie zostoł na noc, nie zrobił żadnych strat ${ }^{53}$.

Wieloletni wypas owiec na halach nauczył pasterzy rozmitych sposób radzenia sobie z niebezpieczeństwami nocy. Dla wielu z nich, szczególnie w przypadku podchodzących wilków lub niedźwiedzi, są nimi przede wszystkim dobrze wyszkolone i ostre psy - niektórzy bacowie trzymają ich nawet kilkanaście $(8,10,12)$ do pilnowania stad:

O 21 owce są zaganiane, coś zjemy i idziemy spać, z owcami śpi juhas, ten co pasie. Cuwamy, ze trzy, ćtery dni temu, wtedy to tyle było wilków, ze nie do uwierzenia, podchodzą wilki, w tym roku mniej, byly takie roki, ze one tu były, tu cała wataha była, osobiście nie widziałem, ale myśliwi mówili, ze widzieli, 9 wilków było, i to musieli my wartować, bo to parę razy bez noc atakowały, bez noc, podchodzą, wyciągają owce, jak nie obocą psy cy juhasi, to wyciągna owcę, wilk to mo głupie, ze bije na zapas, nie tak ze wezmie jedną, jak mo cas, jak nikt mu nie przeskadza, to wybije duzo owiec, jedną zje, restę zostawia, przyjdzie potem, jak tam jest, wróci do tego jedzenia, straty są duże, ale przeważnie juhasi są.

Był taki czas, że zeby odpędzić te wilki, to ogień się palił, ale najwazniejsze to są psy, jak psy nie obocą, to juhas tez nie obacy, psy są dobre. Pies nie da rady wilkowi, wilk wyjdzie co by tak zaś na psa, pies jest strasnie agresywny, jak wilk jest blisko, on tam daleko za nim nie odchodzi, były takie psy, i my tez mieli takiego psa, że nawet tam, gdzie Lasak Andrzej pasie, takiego tam my mieli dobrego psa, ze szedł za wilkiem nawet w las, a jakie tam są lasy, ale go było słychać w nocy, tak daleko go było słychać, szczekoł, ale mało, tak daleko był, ale to nie długo, wilk się nawrócił i na psa. W lesie wilk jest mocny, on sie obróci, psa zagryzie, wtedy jeden na jeden to raczej wilk wygrywa. Jak przychodzą wilki, to pies ujada, to ujadanie wilka odpędzi, ale psy lecą, jak psy lecą, to on tyż ucieka ${ }^{54}$.

52 BT, wywiad z Teresą Miętus, Polana pod Leśniczkówką (okolice Hali Śmietanowej), Zubrzyca Górna, sierpień 2017.

${ }^{53}$ BT, wywiad z Marcelą Plutą, żoną bacy, lat 28, bacówka na Trypsiance/Bacówka na Nowinach, sierpień 2017.

${ }^{54}$ BT, wywiad z bacą Janem Hyrczykiem, Baligówka (Czarny Dunajec), sierpień 2017. 
W momencie zagrożenia pasterze odmawiają również „pacierze”, czyli określone modlitwy przed złymi siłami, krzyk i przekleństwo; dla innych skuteczne są bardziej nowoczesne sposoby, jak petardy czy radio:

No jedynie petardy, szczelać nie wolno, bo są pod ochroną, petardy i radio, radiom, jak już jest tak źle, że chodzą co noc i człowiek nie moze spać, chodzą i psy docinają, to wieszomy w reklamówce radio, nie za głośno, zeby owcom się nie ten, no i wtedy jesce się jei zdarzyło żeby nam podeszły, jak gra radio ${ }^{55}$.

Juhas śpi w koszorze, tam jest taka budka, jak w łóżku, takiej wielkości, tam jest materac i takie dwie zyrdki dłuższe i zadaszenie, ino daszek nabity, to się przenosi, jak się idzie dalej, jakby łożko przenosił, ino z daszkiem. Jak jest niebezpiecznie to są warty, to się zmieniają co noc, wtedy co cwortą noc jest warta, całą noc jest warto, niełatwo. Ale to jest pani krzywdzące, popatrz pani, bo juhasi są od rana, od świtu do nocy i praca ciężka, spania mało i powiem ci pani, jak trzeba w nocy wartować, to jest już przesada. Jo tam rozumie, wilki, nie wilki niech bedą, ale niech nam nie wchodza w szkodę, bo my im nie wchodzimy w szkodę, jak robią skodę, to coś trzeba z tym zrobić, no bo jak, to wilki są wazniejse niż ludzie? Naprawde tego spania mało, jesce to trza pilnować, to to jest toko krzywda dla juhasów, że... To trzeba lubić, to noprowdę trza lubić, zwykły czlowiek to nie wytrzyma, trza być twardym, to bacowanie to jest fajne i honor, ale rodzina na tym cierpi, pewnie, mom dwójke małych dzieci i rzodko je widzę, posedłem na bacówkę, dziewcynka kaj jesce nie chodziła, a juz teroz chodzi, juz mnie coś ominęło, to nie jest takie proste ${ }^{56}$.

\section{ZAKOŃCZENIE SEZONU}

Współcześni pasterze kończą sezon pasterski zazwyczaj na początku października lub w jego drugiej połowie. Przygotowania do rozejścia się rozpoczynają się wraz z końcem września-początkiem października, kiedy to pasterze przechodzą na system jednego dojenia owiec, które trwa około 2-3 tygodni. Po tym czasie następuje stopniowe wygaszanie dojenia, biorąc tu pod uwagę dobrostan zwierząt (co dwa dni, co 4 dni, co parę dni). Zmiany te zależą jednak od warunków pogodowych oraz skupienia mleka (gdy jest coraz gęstsze, dojenia jest mniej). Większość z nich zna dawne powiedzenie, przekazywane im w rodzinach przez pokolenia, które wskazuje na dzień św. Michała (29 września), jako tradycyjny czas zakończenia wypasu owiec w górach: „po świętym Michale ryzyko zostawać w górach”, jednak nie wszyscy z baców biorą je pod uwagę. W zależności od pogody, wielu z nich przedłuża swój pobyt na szałasach, starając się wykorzystać sprzyjające wypasowi warunki. Pasterze starają się pozostać ze stadami na halach tak długo, jak się da, ze względu na dostatek naturalnego pożywienia. Jednak gwałtowne ochłodzenia i deszcze, które przychodzą jesienią w Polsce, powodują, że każdy z baców sam ustala sobie moment zakończenia sezonu pasterskiego i powrotu $z$ hal.

${ }^{55}$ BT, wywiad z Teresą Miętus, Polana pod Leśniczkówką (okolice Hali Śmietanowej), Zubrzyca Górna, sierpień 2017.

${ }^{56}$ BT, wywiad z bacą Janem Hyrczykiem (Pająkiem), wywiad, Baligówka (Czarny Dunajec), sierpień 2017. 


\section{PODSUMOWANIE}

W ostatnich latach pasterstwo przeżywa swoisty renesans w kulturze pogranicza polsko-słowackiego. Dzieje się tak za sprawą nowych projektów finansowanych z funduszy europejskich, jak również samych pasterzy, którzy po okresie zanikania tej profesji w czasach komunizmu, wracają do tradycji „ojców i dziadów”. Etnograficzne badania prowadzone w pasterskich społecznościach lokalnych pokazują, że pasterze traktują swoją profesję jako dziedzictwo kulturowe regionu. Podkreślają, że owe pasterskie zwyczaje mają swoje odległe korzenie w przeszłości, stanowią ich tradycję, którą realizują w życiu codziennym na każdym szałasie polsko-słowackiego pogranicza. Podstawowym elementem dziedzictwa kulturowego pasterzy jest ich stosunek do czasu - zwyczaje i artefakty wykorzystywane przez pasterzy podczas codziennej pracy są przekazywane przez pokolenia w rodzinach pasterskich. Pasterze powtarzając je, nadają im własne sensy i znaczenia, jednocześnie wplatają w cały system współczesnej kultury, co powoduje, że kultura pasterska staje się obecnie swoistym kolażem dawnych i nowych znaczeń i sensów kulturowych, możliwych do odczytywania w różnych konfiguracjach. Wokół wspólnoty szałaśniczej „rozciąga się” również pamięć, która nadaje sens codziennej organizacji, pracy, obrzędom i rytuałom. To właśnie ona pozwala widzieć ciągłość między teraźniejszością, a życiem przodków, sytuuje ona również pasterzy w całym sensie istnienia uniwersum. Jednoczesnie w przestrzeni Karpat istnieją do dziś regiony, na których spotykamy przykłady owej profesji, które wciąż nawiązują do dawnych archaicznych wyobrażeń i praktyk rytualnych. Wiele zwyczajów i obrzędów związanych z szałaśnictwem i pasterstwem tu spotykanych wynika również z tradycyjnego prawa wołoskiego, które co najmniej od XIV wieku sukcesywnie przenikało z terenów bałkańskich, wołoskich, mołdawskich i siedmiogrodzkich do innych regionów karpackich. Do czasów współczesnych wśród górali żyjących w Karapatach przetrwały fragmenty „dawnego świata”, które można odkryć zarówno z artefaktów, jak i ze specyficznych struktur ich myślenia, postrzegania rzeczywistości czy wartościowania rozmaitych zjawisk współczesnego świata.

\section{BIBLIOGRAFIA:}

Abadzi H., The Vlachs of Greece and their Misunderstood History, https://www.academia.edu/3804965/ The_Vlachs_of_Greece_and_their_Misunderstood_History_English [dostęp: 24.11.2015].

Bacowie $\bar{i}$ wałasi. Kultura pasterska na pograniczu polsko-stowackim, red. E. Kocój, J. Michałek, Cieszyn 2018.

Balamaci N. S., Can the Vlachs write their own history?, "Journal of Hellenic Diaspora" 1991, 17, Januar, pp. 9-36, http://pl.scribd.com/doc/46327940/Can-the-Vlachs-Write-Their-Own-History\#scribd [dostęp: 31.10 .2015$]$.

Co słychać na podhalu. Tradycja we współczesności, red. M. Małanicz-Przybylska, Warszawa 2014.

Czajkowski J., Dzieje osadnictwa historycznego na Podkarpaciu i jego odzwierciedlenie w grupach osadniczych [w:] Łemkowie w historii i kulturze Karpat, Rzeszów 1992. 
Czamańska I., Wołosi i Słowianie w średniowieczu i epoce nowożytnej, „Res Historica”, 2016, 41, 42, s. 11-23.

Czamańska I., The Vlachs - several research problems, „Balcanica Posnaniensia Acta et studia, 2015, v. 22, n. 1, s. 7-16.

Dobrowolski K., Studia nad kulturą pasterska Karpat Pólnocnych, ,Wierchy”, 1960, nr 29.

Dziedzictwo niematerialne, http://www.unesco.pl/kultura/dziedzictwo-kulturowe/dziedzictwo-niematerialne/ [dostęp: 02.05.2018].

Gorali. Vel'ka kniha o goralach Oravy, Liptova a Kysúc, red. M. Jasensky, Martin 2013.

Grzesik R., Blachowie i pastores Romanorum w Gesta Hungarorum Anonimowego Notariu-sza, ,Res Historica" 2016, n. 41, s. 25-34.

Grzesik R., The Valachian way of life in stories about domestic origins in the Hungarian me-dieval chronicles, ,

Balcanica Posnaniensia Acta et studia”, 2015, v. 23, s. 167-174

Guidelines for the Establishment of National "Living Human Treasures” Systems, http://www.unesco.org/ culture/ich/doc/src/00031-EN.pdf [dostęp: 03.08.2015].

Herniczek-Morozowa W., Terminologia polskiego pasterstwa górskiego, część 1, Wrocław-WarszwaKraków-Gdańsk 1975.

Húšt'avová M., Pasterstwo w kulturze kulturowej Karpat, Kultura pasterska we współczesności karpackiej z uwzględnieniem regionu Babiej Góry, red. B. Rosiek, K. Słabosz-Pałacz, Zawoja 2015.

Janicka-Krzywda U., Magia hal i połonin [w:] Pasterstwo w Karpatach. Tradycja a współczesność. Szkice, red. M. Kiereś, Warszawa 2014.

Jawor G., Osady prawa wołoskiego i ich mieszkańcy na Rusi Czerwonej w późnym średniowieczu, Lublin 2004.

Jostowa W., Pasterstwo na polskiej Orawie, Zakopane 1972.

Jovanovski D., Minov N., Ioannis Kolettis. The Vlach from the ruling elite of Greece, „Balcanica Posnaniensia. Acta et studia", 2017, ss. 221-239.

Kahl, T., Ethnizität und räumliche Verbreitung der Aromunen in Südosteuropa, Münster 1999.

Kiereś M., O gospodarce sałaszniczo-pasterskiej w etnograficznej pigutce, [w:] Owce w Beskidach, Istebna 2010.

Kiereś M., Współczesny kontekst zmian w obyczajowości tradycyjnej kultury pasterskiej w Karpatach, Kultura pasterska we współczesności karpackiej z uwzględnieniem regionu Babiej Góry, red. B. Rosiek, K. Słabosz-Pałacz, Zawoja 2015.

Kocój E., Dziedzictwo kulturowe mniejszości narodowych, etnicznych i religijnych kręu Karpat - narracje lokalne $i$ zarzadzanie instytucjonalne (wstępne rezultaty badania pilotażowego), „Prace Etnograficzne", 2016, z. 3, s. 193-213.

Kocój E., Pamięć starych wieków. Symbolika czasu w rumuńskim kalendarzu prawosławnym, Kraków 2013.

Kocój E., Artefakty przeszłości jako ślady pamięci. Dziedzictwo kulturowe Aromanów (Wołochów) na Bałkanach, „Prace Etnograficzne”, 2015, z. 4, s. 271-305.

Kocój E., Sacrum i przestrzeń. Hierotopia wyspy Kefalonii w Grecji (wstępne rezultaty badania pilotażowego), „Łódzkie Studia Etnograficzne”, 2017, 56, s. 125.

Kocój E., The Story of an Invisible City. The Cultural Heritage of Moscopole in Albania. Urban Regeneration, Cultural Memory and Space Management [w:] Intangible heritage of the City. Musealisation, preservation, education, ed. By M. Kwiecińska, Kraków 2016, ss. 267-280.

Kopczyńska-Jaworowska B., Gospodarcze i społeczne podstawy pasterstwa tatrzańskiego [w:] Historia osadnictwa i organizacja społeczna pasterstwa oraz słownictwo pasterskie, oprac. S. Górzyński [et al.]., Seria: Pasterstwo Tatr Polskich i Podhala, Wrocław 1962, s. 107-162.

Koukoudis A.I., The Vlachs: Metropolis and Diaspora, Thessalonica 2003.

Luković M., Zakon vlahom (Ius Valachicum) in the charters issued to Serbian medieval monasteries and kanuns regarding Vlachs in the early ottoman tax registers (defters), „Balcanica Posnaniensia”, XXII/1 - IUS VALACHICUM I, Poznań - Bucharest 2015, s. 29-45. 
Niculiţa-Voronca E., Datinele şi credinţele poporului român adunate şi aşezate în ordine mitologică, Bucureşti 1998.

Nowicka E., Etniczna tożsamość Arumunów/Wlachów w XXI stuleciu, „Res Historica”, 2016, 41, s. 213 235.

Minov N., Titsi shi cum eara internats Armãnjlji di Crushuva tu chirolu a Protlui Polim Mundial? (Никола Минов, Зошто и како беа интернирани крушевските Власи за време на Првата светска војна?) [w:] 100 di anj de proclamarea a principatului armãnescu Pindu shi 100 di anj de deportarea Armãnjor, Skopje 2017, ss. 111-142.

Oczko A., Traces of Vlach Migrations in the Toponymy of the Polish Podtatrze Region, „Res Historica”, 2016, 41, s. 151-158.

Pasterstwo Tatr polskich i Podhala, pr. zbiorowa, red. W. Antoniewicz, t. 1-8, Wrocław 1959-1970.

Pasterstwo w Karpatach. Tradycja a wspótczesność. Szkice, red. M. Kiereś, Centrum UNEP/GRIDWarszawa@Grafikon, Warszawa 2014.

Sendyka P., Makovicky N., Transhumant pastoralism in Poland:Contemporary challenges, Pastoralism: Research, Policy and Practice, (2018) 8:5

Sajkowski W., The Peoples Inhabiting the Illyrian Provinces Known under the Name of Morlachs Definition of the Ethnonym in the Light of the French Literature, „Res Historica”, 2016, 41, s. 111123.

Szyfer A., Słownictwo pasterskie Tatr i Podhala, [w:] Historia osadnictwa i organizacja społeczna pasterstwa oraz stownictwo pasterskie, oprac. S. Górzyński [et al.]., Seria: Pasterstwo Tatr Polskich i Podhala, Wrocław 1962, s. 162-193.

Taminden T., The Vlach in the Republic of Macedonia. A Success Story or a Minority on Road to Extinction?, [w:] The Forgotten Minorities in of Eastern Europe - the History and Today of selected ethnic groups in five countries, ed. A. Tanner, Helsinki 2004.

Zuskinova I., Liptov - l'udové umenie, OZ Spoločnost' priatel’ov Múzea liptovskej dediny, 2017. 
